
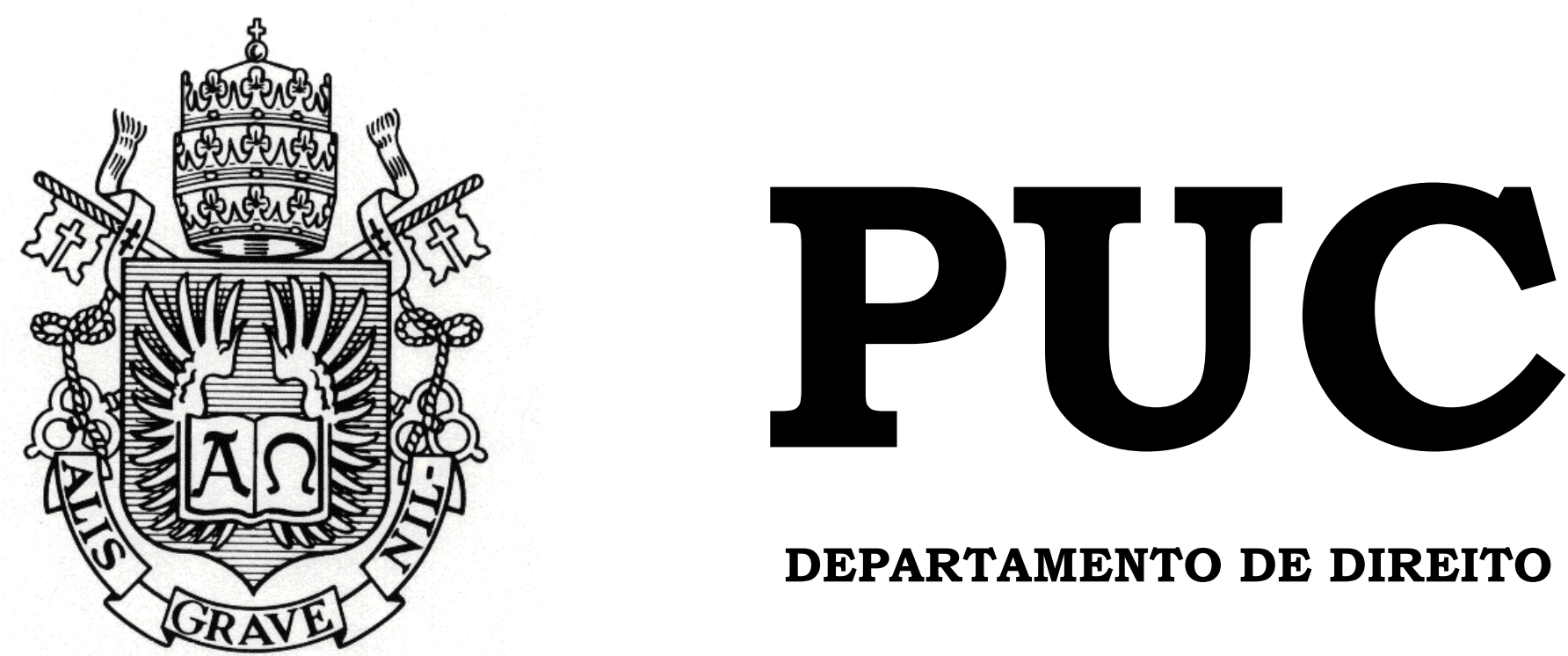

DEPARTAMENTO DE DIREITO

\title{
DIREITO DE RESPOSTA
}

por

SOFIA GLASHERSTER

ORIENTADOR: FÁBIO CARVALHO LEITE

2018.2

PONTIFÍCIA UNIVERSIDADE CATÓLICA DO RIO DE JANEIRO

RUA MARQUÊS DE SÃO VICENTE, 225 - CEP 22453-900

RIO DE JANEIRO - BRASIL 


\title{
DIREITO DE RESPOSTA
}

\author{
por
}

\section{SOFIA GLASHERSTER}

Monografia apresentada ao Departamento de Direito da Pontifícia Universidade Católica do Rio de Janeiro (PUC-Rio) para a obtenção do Título de Bacharel em Direito.

Orientador: Fábio Carvalho Leite 


\section{AGRADECIMENTOS}

Aos meus pais (os quatro), por tornarem isso possível e serem exemplos tão distintos e importantes para mim. Também à minha irmã e amigos próximos, especialmente aos que tiraram um pouco do seu tempo para me ajudar com esse trabalho. Sem vocês nenhuma caminhada valeria a pena (ainda que valesse, não teria a menor graça).

Ao meu orientador, por ter inspirado e ajudado a construir essas páginas. 


\section{RESUMO}

A proposta do presente trabalho é apresentar o direito de resposta com o objetivo de potencializar sua utilização como instrumento de solução dos conflitos entre liberdade de expressão e direitos da personalidade. Estudos precedentes apontam a prática judiciária brasileira de adotar posição preferencial aos direitos da personalidade e, consequentemente, de restrição à liberdade de expressão. A partir da identificação desse problema e do reconhecimento da condenação civil como possível forma de autocensura e resfriamento do debate público, serão analisados os pressupostos para a concessão ou não do direito de resposta, bem como investigar qual o tratamento dado ao direito de resposta no Tribunal de Justiça do Estado do Rio de Janeiro, entre os anos de 2016 e 2018. O objetivo é identificar como o direito de resposta vem sendo aplicado, especificamente após a Lei Federal $n^{0} 13.188 / 2015$, bem como analisar sua relação com a condenação em indenização.

Palavras-Chave: direito de resposta; liberdade de expressão; censura judicial; indenização. 


\section{SUMÁRIO}

Introdução 6

Capítulo 1 - A condenação civil e seus efeitos à liberdade de expressão 8 1.1 - Insegurança jurídica nos julgados envolvendo o conflito entre liberdade de expressão e direitos da personalidade ...........8 1.2 - Consequências da condenação civil: autocensura e resfriamento do debate público ................................................ 10

1.3 - Casos emblemáticos ....................................................... 14

1.3.1 - Críticas de sindicato ao governo.......................... 15

1.3.2 - Debate eleitoral .............................................. 15

1.3.3 - "Violência institucional" aos jornalistas............... 17

Capítulo 2 - Direito de resposta ..................................................... 20

2.1 - Introdução ...................................................................... 20

2.2 - Conceito e funções do direito de resposta........................ 20

2.3 - Requisitos para a concessão ou não do direito de resposta 27

2.4 - Conceito de "matéria" ..................................................... 29

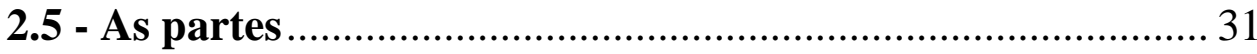

2.5.1 - Polo ativo ............................................................ 31

2.5.2 - Polo passivo .................................................... 33

2.6 - Diferenças do direito de resposta eleitoral ...................... 34

Capítulo 3 - Tratamento dado ao direito de resposta pelo Tribunal de Justiça do Estado do Rio de Janeiro (2016-2018) ................................ 36

3.1 - Objetivos ................................................................. 36

3.2 - Metodologia da pesquisa ................................................. 36

3.3 - Análise dos resultados ..................................................... 36

3.3.1 - Dados quantitativos dos resultados..................... 37 
3.3.2 - Apontamento dos principais fundamentos utilizados para a concessão do direito de resposta ............................... 38 3.3.3 - Apontamento dos principais fundamentos utilizados para o indeferimento do direito de resposta 43

Conclusões 49

Bibliografia 53 


\section{INTRODUÇÃO}

Muitas são as discussões sobre o conflito entre a liberdade de expressão e outros direitos constitucionais igualmente protegidos (como a honra e a privacidade), assim como muitas são as discussões quanto às formas de solução desses embates.

O presente trabalho foca em analisar o Direito de Resposta, consagrado no artigo $5^{\circ}$, inciso $\mathrm{V}$ da Constituição de 1988 , mas ainda tímido na solução dos conflitos supracitados.

O objeto do primeiro capítulo é discorrer sobre os efeitos da condenação civil à liberdade de expressão. Chama atenção que, em um ranking mundial sobre liberdade de imprensa, entre 180 países, o Brasil está em $102^{\mathrm{a}}$ e é caracterizado como "um ambiente de trabalho cada vez mais instável. Ameaças, agressores durante manifestações, assassinatos (...) inúmeros jornalista investigativos são alvo de processos judiciais abusivos" $"$. Especificamente quanto ao último ponto, o primeiro capítulo busca mostrar a insegurança jurídica nas decisões envolvendo o conflito entre a liberdade de expressão e direitos da personalidade, bem como as consequências causadas. Para finalizar o primeiro capítulo, foram apresentados três casos concretos em que houve a condenação civil e, quando possível, foram trazidas as notas do réu sobre as consequências dessa condenação.

Feita essa apresentação do problema, o segundo capítulo passa a discutir o direito de resposta, especificamente quanto ao seu objeto de aplicação e os requisitos considerados pela doutrina para a sua concessão.

No terceiro capítulo, foram investigados os casos tratando do direito de resposta no Tribunal de Justiça do Estado do Rio de Janeiro, entre os anos de 2016 a 2018. Após apresentar a metodologia da pesquisa, foram apontados os principais critérios utilizados nas decisões para conceder ou não o direito

\footnotetext{
${ }^{1}$ Disponível em <https://rsf.org/pt/brasil $>$. Acesso em 27 jun. 2018.
} 
de resposta. Além disso, foi feita uma breve análise estatística dos julgamentos a fim de testar a hipótese de a concessão do direito de resposta vir ou não acompanhada da condenação civil.

Como resultado, é esperado que esse trabalho possa identificar o tratamento dado ao direito de resposta pelo Tribunal de Justiça do Rio de Janeiro, com os limites da pequena amostra temporal analisada (2016-2018) e verificar se estão ou não presentes os mesmos requisitos trazidos pela doutrina. Em sentido mais amplo, esse trabalho espera trazer ao debate da liberdade de expressão as potencialidades do direito de resposta a fim de que possa ser mais utilizado, quando atendidos seus requisitos, como meio anterior à condenação civil. 


\section{CAPÍTULO 1 - A condenação civil e seus efeitos à liberdade de expressão}

\section{1 - Insegurança jurídica nos julgados envolvendo o conflito entre liberdade de expressão e direitos da personalidade}

Chequer (2011, p. 71. e 203/204), ao analisar julgados dos Tribunais Estaduais de Minas Gerais, Rio de Janeiro, São Paulo, Rio Grande do Sul, Paraná, Distrito Federal e do Superior Tribunal de Justiça, concluiu que na grande maioria dos casos envolvendo conflitos posteriores entre a liberdade de expressão e os direitos da personalidade, os julgados dão preferência a esses em detrimento daqueles ${ }^{2}$, mesmo em assuntos de interesse público ${ }^{3}$, embora, introdutoriamente, quase todos os julgados falem sobre o princípio da ponderação.

O mesmo não se verifica quando o conflito entre a liberdade de expressão e os direitos da personalidade ocorre de forma prévia. Nesses casos, as decisões judiciais privilegiam a liberdade de expressão invocando a proibição da censura (Chequer, 2011, p. 204). Contudo, registre-se a existência, em pequena proporção, de decisões proibindo a divulgação do conteúdo 4 .

\footnotetext{
2 "Uma pesquisa realizada junto ao Superior Tribunal de Justiça, levantando decisões (em Recursos Especiais e apenas na esfera cível) sobre os conflitos entre liberdade de expressão e direitos da personalidade em geral, no período de 2002-2010, revelou que, num universo de 57 acórdãos, somente em 12 o tribunal entendeu que deveria prevalecer o direito à liberdade de expressão" (Leite, 2014, não paginado).

${ }^{3}$ Sobre o conceito de "interesse público", ressalta-se que há uma indefinição dos seus contornos, como é apontado no Relatório de Pesquisa de Iniciação Cientifica disponível em <http://www.puc-rio.br/pibic/relatorio_resumo2017/relatorios_pdf/ccs/DIR/DIRCarolina\%20Berenger.pdf $>$. Acesso em 30 set. 2018.

${ }^{4}$ O Relatório de Liberdade de Imprensa (2014-2016), elaborado pela Associação Nacional de Jornais, além de trazer números alarmantes sobre agressões, mortes, prisões, atentados e ameaças aos jornalistas no Brasil, aponta também 9 casos de censuras judiciais entre agosto de 2014 a agosto de 2016. Diante dos casos relatados, parece ter sido adotada a definição de censura judicial de acordo com a existência de decisões judiciais proibindo a divulgação do conteúdo - mesmo sendo posteriormente reformada -, a exceção é o caso de fevereiro de 2016: "Juizes e promotores do Paraná iniciaram uma série de ações contra os repórteres Francisco Botelho Marés de Souza, Rogério Galindo e Euclides Garcia, o analista de sistemas Evandro Balmant, e o infografista Guilherme Storck, do jornal Gazeta do Povo, de Curitiba (PR). As ações somam R $\$ 1,4$ milhão em pedidos de indenizações. Os
} 
O mesmo cenário de incoerência é indicado por Leite, conforme

relato abaixo:

\begin{abstract}
"A incoerência das decisões judiciais pode ser facilmente verificada pela variação de entendimento pelas diversas instâncias que julgam um mesmo processo sendo que, no final, de todo modo, ela só afetará as partes no processo. A compreensão do direito a partir das decisões judiciais - e, diante da ausência de regras, esse deveria ser o caminho mais adequado - é quase caricata. Um cidadão, em seu blog, pode chamar uma prefeita (Rosinha Garotinho) de 'caloteira' e 'despreparada' (TJRJ, 7 $7^{\mathrm{a}}$ Câmara Cível, Apelação Cível $\mathrm{n}^{\mathrm{o}}$ 001804151.2012.8.19.0014), e internautas, em outro blog, também podem acusá-la de roubo de dinheiro público, venda dos royalties do petróleo, péssima gestora, responsável por rombo nos cofres públicos (TJRJ, $7^{\text {a }}$ Câmara Cível, Apelação Cível $\mathrm{n}^{\circ}$ 0035937-39.2014.8.19.0014), mas o marido da prefeita (Anthony Garotinho), em seu blog, não pode chamar o então vice-governador Pezão de 'Mãozão' (TJRJ, $7^{\mathrm{a}}$ Câmara Cível, Apelação Cível $\mathrm{n}^{\mathrm{o}}$ 002270936.2014.8.19.0001), ao tratar do sumiço de verbas destinadas às vítimas das chuvas na Baixada Fluminense. De acordo com a 'jurisprudência', o ordenamento jurídico brasileiro também não permite que um blogueiro chame um Ministro de Estado de 'sem vergonha' ('Crivella é 100 vergonha'), acusando-o de usar dinheiro público para beneficiar ONG ligada à sua igreja (TJRJ, $21^{\text {a }}$ Câmara Cível, Agravo de Instrumento $\mathrm{n}^{\circ}$ 0068778- 66.2013.8.19.0000), mas permite que um jornalista chame o prefeito de sua cidade, no interior, de 'criminoso', 'canalha', 'desonesto e ladrão' (TJRJ, 9a Câmara Cível, Apelação Cível ${ }^{\circ}$ 0002154-66.2009.8.19.0035), embora não permita que um exprefeito de outra cidade seja chamado de 'mentiroso, mal caráter, ladrão, canalha, cara de pau e apedeuta' (TJRJ, $7^{\mathrm{a}}$ Câmara Cível, Apelação Cível $\mathrm{n}^{\mathrm{o}}$ 002222838.2012.8.19.0003). Por outro lado, um cidadão pode (TJSC, $3^{\mathrm{a}}$ Câmara de Direito Civil, Apelação Cível 306498 SC 2003.030649-8) mas na verdade não pode (STJ, Recurso Especial no 801249 ) afirmar que um deputado estadual 'tem uma incrível facilidade de mentir', e um jornal talvez possa (TJRJ, $3^{\text {a }}$ Câmara Cível, Apelação Cível n. ${ }^{\circ}$ 0158666-82.2009.8.19.0001) ou talvez não possa (TJRJ, 3a Câmara Cível, Apelação Cível n. ${ }^{\circ}$ 0152792-19.2009.8.19.0001) publicar a foto de uma mulher, de costas, que se encontrava sentada no vaso sanitário, de calças arriadas enquanto era resgatada pelos bombeiros, num edifício onde dois andares desabaram." (Leite, 2018, p. 9/10).
\end{abstract}

Considerando que "a transformação dos textos normativos em normas jurídicas depende da construção de conteúdos de sentido pelo próprio intérprete" (Ávila, 2009, p. 24), a solução judicial de admitir que "a liberdade de expressão pode ser exercida sempre, desde que não atinja os direitos da

magistrados pediram indenizações por danos morais por reportagens que divulgaram os rendimentos dos membros do Judiciário e do Ministério Público do Estado. Em uma das matérias, o jornal mostrou que os magistrados receberam $R \$ 527$ mil e $R \$ 507$ mil, quando o teto é de $R \$ 411$ mil. Todos os dados usados na reportagem são públicos e disponíveis no Portal da Transparência do Tribunal de Justiça do Paraná (TJ-PR)" (p. 27). Disponível em <http://www.anj.org.br/relatorios-2/>. Acesso em 27 jun. 2018. 
personalidade" (Chequer, 2011, p. 207), nega a essência da garantia à liberdade de expressão:

"A liberdade de expressão não é prevista como direito fundamental pela Constituição para assegurar o direito de fazer elogios ou de manifestar opiniões favoráveis. A liberdade de expressão existe para garantir o direito de discordar, de criticar; às vezes até de ofender." (Mello, 2016, p. 157).

Afinal, a necessidade da garantia à liberdade de expressão é diretamente proporcional ao tom crítico do discurso e "entender de outra forma significaria reconhecer que a liberdade de expressão protege apenas o conteúdo que a ninguém interessa censurar" (Leite, 2014, não paginado). Se um homem não tem garantia para poder criticar livremente, seus elogios não têm valor algum (Marx, 1980, p. 58).

Soma-se a isso a posição majoritária da doutrina defendendo a aplicação do princípio da ponderação de interesses (Chequer, 2011, p. 203), contribuindo para o "terreno da pura subjetividade" do juiz (Mello, 2016, p. $152 / 153)^{5}$.

Isso explica (mas não justifica) a ausência de parâmetros decisórios sobre o tema e a consequente insegurança jurídica gerada (Mello, 2016, p. $153)$.

Há a garantia da possibilidade de divulgar o conteúdo e incerteza acerca de eventual condenação judicial (Leite, 2014, não paginado), que atinge especialmente "às pessoas que resolvem expor publicamente as suas ideias, relatar fatos, formular denúncias ou manifestar por qualquer meio seu pensamento" (Mello, 2016, p. 154.)

\section{2 - Consequências da condenação pecuniária: autocensura} e resfriamento do debate público

\footnotetext{
${ }^{5}$ Mello (2012, p. 142), ao analisar julgados do Supremo Tribunal Federal acerca do conflito entre a liberdade de expressão com os direitos à honra, à privacidade ou à imagem, concluiu que os ministros julgam os casos através de um juízo de ponderação, dando mais margem ao entendimento pessoal do juiz influenciar na decisão e, com isso, contribui para a ausência de critérios na jurisprudência sobre o tema.
} 
Pelos motivos que serão apresentados a seguir, além da definição clássica de censura, é também englobada na definição o ato judicial de condenar em indenização quem anteriormente manifestou seu pensamento.

A chamada "definição clássica" de censura seria

\begin{abstract}
"A censura prévia significa o controle, o exame, a necessidade de permissão a que se submete, previamente, e com caráter vinculativo, qualquer texto ou programa que pretende ser exibido ao público em geral. O caráter preventivo e vinculante é o traço marcante da censura prévia, sendo a restrição à livre manifestação de pensamento sua finalidade antidemocrática. O texto constitucional repele frontalmente a possibilidade de censura prévia. Essa previsão, porém, não significa que a liberdade de imprensa é absoluta, não encontrando restrições nos demais direitos fundamentais, pois a responsabilização posterior do autor e/ou responsável pelas notícias injuriosas, difamantes, mentirosas sempre será cabível, em relação a eventuais danos materiais e morais." (Moraes, 2005, p. 223).
\end{abstract}

"Por essa perspectiva, censura seria a forma de controle prévio da liberdade de expressão pela qual certos conteúdos devem receber o aval do Estado antes de serem publicados. Em contrapartida, a responsabilidade ulterior não seria uma forma de censura, mas um mecanismo legítimo de reparação de danos oriundos de expressões efetivamente manifestadas" (Leahy, 2013, p. 363).

Inclusive, essa é a definição de censura que parece prevalecer no Supremo Tribunal Federal:

\footnotetext{
"Esta Corte, no julgamento da ADPF 130/DF, Rel. Min. Ayres Britto, assentou que não constitui forma de censura à imprensa a responsabilização penal, civil ou administrativa, a posteriori, de veículo de comunicação em razão de dano moral por ele causado ante a publicação de matéria jornalística. BRASIL. Supremo Tribunal Federal. ARE 650931 AgR. Relator: Min. Ricardo Lewandowski, Segunda Turma, julgado em 26/06/2012. Publicado no DJe-158 em 13/08/2012" (Leahy, 2013, p. 364).
}

Essa definição de censura é considerada "mais tradicional e formalista" e "vislumbra uma distinção constitucional entre restrições prévias e responsabilidades ulteriores" (Leahy, 2013, p. 363).

Embora a condenação civil admita formalmente a circulação do conteúdo, ao mesmo tempo aplica uma sanção pecuniária. Mesmo que o fato que originou a condenação continue disponível, a decisão conclui que esse ato configura um ilícito civil. 
Apesar da inexistência de obstáculos formais à publicação do conteúdo, o condenado a uma determinada quantia, em razão da divulgação de críticas à honra de alguém ${ }^{6}$ (mas que podem ter contribuído para o debate público), pode eventualmente deixar de manifestar suas opiniões e essa decisão pode influenciar outros comunicadores a também deixarem (o chamado "chilling efect"), esfriando o debate público (Leite, 2014, não paginado). A tendência do emissor, se não é renunciar a palavra, é ou ao menos reavaliá-la (Mello, 2016, p. 70), principalmente se não puder assumir os riscos de uma eventual condenação judicial (Toller, 2010, p. 56).

Um possível exemplo disso é o caso da atriz Mônica Iozzi, condenada ao pagamento de $\mathrm{R} \$ 30.000,00$ (trinta mil reais) em favor do ministro Gilmar Mendes, por causa de uma postagem que fez em seu Instagram, ao criticar uma decisão do ministro. Ao ser questionada em entrevista sobre o caso, expressou "falar do Gilmar Mendes eu posso falar, mas já posso começar a juntar um dinheiro da plateia para caso eu seja processada novamente"7.

É possível concluir que uma visão formalista da liberdade de expressão e a consequente resposta dada pelo Direito através de uma condenação pecuniária tem capacidade inibitória, os quais podem gerar autocensura e resfriamento do debate público sobre a futura expressão de terceiros, inclusive as legítimas (Mello, 2016, p. 16, Leite, 2014 e Toller, 2010, p. 50).

Nesse sentido reconheceu o Tribunal Europeu de Direitos Humanos:

"although the penalty imposed on the author did not strictly speaking prevent him from expressing himself, it nonetheless amounted to a kind of censure, which would be likely to discourage him from making criticisms of that kind again in

\footnotetext{
${ }^{6}$ Esse "alguém" pode referir-se tanto a pessoa física como pessoa jurídica. "STF - 'Não ofende o inciso $\mathrm{X}$ do art. $5^{\circ} \mathrm{da} \mathrm{CF} / 88$ ('são invioláveis a intimidade, a vida privada, a honra e a imagem das pessoas, assegurado o direito de indenização pelo dano material ou moral decorrente de sua violação;') o reconhecimento, à pessoa jurídica, do direito à indenização por dano morais, em razão de fato considerado ofensivo à sua honra' (STF $-2^{\mathrm{a}} \mathrm{T}$. $-\mathrm{AG}$ (AgRg) 244.072/SP - Rel. Min. Néri da Silveira, Informativo STF, 10 abr. 2002, n 262, p.2)" (Moraes, 2005, p. 225).

${ }^{7}$ Disponível em <https://www.youtube.com/watch?v=BmOYcO9LHh8>. Acesso em 27 jun. 2018.
} 
future; the Delegate of the Commission rightly pointed this out. In the context of political debate such a sentence would be likely to deter journalists from contributing to public discussion of issues affecting the life of the community. By the same token, a sanction such as this is liable to hamper the press in performing its task as purveyor of information and public watchdog" (Corte Europeia de Direitos Humanos, Linges v. Austria, Strasbourg, 08 jul. 1986).

A autocensura e o chamado "chilling efect" podem, inclusive, serem mais difíceis da sociedade combater do que a própria censura prévia, uma vez que não há responsáveis diretos.

Esse contexto é ainda pior no Brasil dada a alta desigualdade vivida no país,

\begin{abstract}
“o bônus é compartilhado com o público, enquanto o ônus é suportado exclusivamente por quem se expressa. Há um preço a ser pago - o que, no sentido literal, é algo a ser considerado numa sociedade que é a $10^{\mathrm{a}}$ mais desigual em todo o mundo (índice de Gini 0,515 em 2015), ao lado da Suazilândia e abaixo de países como Guiné-Bissau $\left(11^{\mathrm{a}}\right)$, Ruanda $\left(14^{\mathrm{a}}\right)$ e Congo $\left(15^{\mathrm{a}}\right)$. Significa dizer que, no Brasil, alguns poucos podem assumir riscos que a grande maioria não pode e, se traduzimos a liberdade de expressão e de imprensa a partir dos riscos de sanções pecuniárias, podemos dizer que para alguns poucos indivíduos e grupos empresariais a liberdade de expressão e de imprensa, 'na prática', seria, de certo modo, um direito absoluto (considerando-se a insignificância da indenização pecuniária)." (Leite, 2018, p. 6).
\end{abstract}

No cenário atual, a liberdade de pensamento é garantida somente àqueles que podem assumir os riscos de pagar eventuais condenações judiciais. Essa sistemática torna-se mais grave se considerarmos a já existente concentração dos meios de comunicação nas mãos de poucos grupos ${ }^{9}$ e que "há casos em que os valores indenizatórios chegam a patamares tão elevados que levam ao fechamento de pequenos jornais, o que cerceia a difusão de ideias e compromete a liberdade de imprensa local" (Leahy, 2013, 364).

\footnotetext{
${ }^{8}$ Tradução livre: "embora a penalidade imposta ao autor não o impedisse estritamente de se expressar, ainda assim representava uma espécie de censura, o que provavelmente o desencorajaria de fazer críticas desse tipo novamente no futuro; o Delegado da Comissão salientou com razão. No contexto do debate político, tal sentença provavelmente impediria os jornalistas de contribuir para a discussão pública de questões que afetam a vida da comunidade. Da mesma forma, uma sanção como esta é susceptível de dificultar a imprensa no desempenho de sua tarefa como fornecedora de informações e vigilância pública".

9 "Na área de radiodifusão (rádio e televisão), três conglomerados nacionais e cinco grupos regionais midiáticos atingem quase 100\% do território brasileiro" (Cabral, 2015, p. 19)
} 
Ainda há a peculiaridade de jornalistas processarem jornalistas no Brasil (Mello, 2016, p. 69/70), permitindo que

\footnotetext{
"os proprietários dos grandes meio de comunicação utilizam-se de jornalistas empregados em suas empresas de comunicação para calar, por estrangulamento econômico, jornalistas de opinião diversa. $\mathrm{O}$ objetivo talvez seja manter um controle absoluto sobre a informação" (Mello, 2016, p. 78.)
}

No Brasil "são os juízes os agentes do estado a quem se pede e de quem se obtém a censura à livre manifestação do pensamento" (Mello, 2016, p. 71).

Admitir a impossibilidade de ambos os direitos serem tutelados, implica afirmar qual conteúdo está ou não protegido: "ou aquele que se manifesta estará impedido de fazê-lo ou aquele que sofreu o dano terá que suportá-lo" (Leite, 2014, não paginado). Nessa linha,

\footnotetext{
"a censura deveria ser vista por um prisma material, de modo a abranger não apenas o controle prévio da manifestação do pensamento, mas também as sanções civis, penais ou administrativas que resultem das expressões exteriorizadas. Por essa linha, caberia falar tanto em censura prévia, como em censura a posteriori (também conhecida como ex post facto).” (Leahy, 2013, p. 364).
}

Por isso, para analisar o verdadeiro problema da liberdade de expressão é importante verificar "a efetiva supressão de expressões legítimas ou constitucionalmente protegidas", independente do momento em que a medida restritiva é tomada (Leahy, 2014, 365).

\section{3 - Casos emblemáticos}

Nesse subcapítulo, serão expostos casos considerados emblemáticos de condenações civis àqueles que decidem expor sua opinião, a fim de exemplificar a falta de parâmetros objetivos nos processos decisórios, relacionados ao livre exercício da manifestação do pensamento (subcapítulo 1.1), bem como o possível efeito silenciador nas "expressões legítimas ou constitucionalmente protegidas" (Leahy, 2014, 265) (subcapítulo 1.2). 


\subsection{1. - Críticas de sindicato ao governo}

O Sindicato dos Trabalhadores em Educação do Estado de Rondônia e o seu presidente foram condenados ao pagamento, cada um, no valor de $\mathrm{R} \$$ 18.000,00 (dezoito mil reais), totalizando $\mathrm{R} \$ 36.000,00$ (trinta e seis mil reais), em favor do Governador de Rondônia (José de Abreu Bianco), em razão de terem colocado:

\footnotetext{
"outdoors em espaços públicos da Cidade de Rondônia-RO, com as mensagens 'TRAIDORES DO POVO - Bianco demitiu quase 10 mil servidores' e 'Estes parlamentares não fizeram nada para impedir, e ainda ficaram do lado do Governador contra os servidores', acompanhadas de fotos do recorrido e de outros parlamentares (...) Tal fato restou difundido na mídia, em especial no Jornal Diário da Amazônia" (STJ, Recurso Especial no 530.805/RO, Rel. Ministro Massami Uyeda, Brasília, 07 dez. 2006).
}

No Superior Tribunal de Justiça, a condenação foi mantida porque entendeu-se que inexistiria "cunho crítico ou jornalístico", tendo as ofensas único intuito de "atingir a honra objetiva e subjetiva" do governador, "sendo desnecessária a prova do prejuízo, mas apenas a existência de fato capaz de gerar constrangimento" (STJ, Recurso Especial n 530.805/RO, Rel. Ministro Massami Uyeda, Brasília, 07 dez. 2006).

\subsection{2. - Debate eleitoral}

O Superior Tribunal de Justiça reformou decisão do Tribunal de Justiça de São Paulo para condenar o político Paulo Maluf a pagar ao governador, à época, Geraldo Alckmin o valor de $\mathrm{R} \$ 35.000,00$ (trinta e cinco mil reais). O fato que resultou na condenação foi a crítica feita por Paulo Maluf, através de nota subscrita e distribuída aos principais jornais do País, onde questionada o uso do dinheiro público dado pelo governo paulista de Alckmin, pois este custearia viagem dos membros do Ministério Público para investigar os opositores do seu governo, enquanto essa mesma velocidade não seria dada nas investigações de eventuais crimes no superfaturamento das obras do Rodonel, realizadas pelo governo de Alckmin. 
Apesar de ser ressaltado no julgado que "as críticas e os debates relativos a programas políticos e problemas sociais são de suma importância, especialmente para formação da convicção do eleitorado", foi sopesado que ${ }^{10}$

"a pretexto de criticar o mau uso do dinheiro público, não enunciou propósito específico de denunciar a conduta do recorrente, mas, ao revés, uma forma subreptícia de impingir-lhe conduta criminosa, em verdadeiro abuso de direito, valendo-se de expressões permeadas de insinuações maledicentes; tudo isso, tão somente, por se tratar de adversário político" (STJ. Recurso Especial $\mathrm{n}^{\circ}$ 1.169.337/SP, Rel. Ministro Luis Felipe Salomão, Brasília, 18 nov. 2014).

Vale trazer trecho do acórdão reformado, o qual julgou no sentido oposto ao Superior Tribunal de Justiça, porque

"observa-se que o principal objetivo do apelante era se defender das investigações que estavam sendo feitas contra sua pessoa, criticando a forma como estavam sendo procedidas" (TJ-SP. Apelação Cível no 0041080-76.2002.8.26.0000, Rel. Desembargadora Fernanda Camacho, 30 jan. 2006).

No fim, foi decidido que "o limite para a informação ou expressão de manifestação é o da honra da pessoa atingida". Para a fixação do total de $\mathrm{R} \$ 36.000,00$ (trinta e seis mil), a título de dano moral, foram considerados os seguintes julgados:

"No REsp. 801.249 (Terceira Turma), em que se tratava de imputação da pecha de "mentiroso" a adversário político, esta Corte fixou o montante indenizatório em R \$20.000,00 (cerca de 50 salários mínimos vigentes em 2007); no REsp. 585.388 (Terceira Turma), que tratava de matéria inverídica ofensiva à honra do recorrente, foi fixada a indenização em $\mathrm{R} \$ 12.000,00$ (cerca de 46 salários mínimos vigentes em 2004); no REsp. 348.388 (Quarta Turma), cuja matéria jornalística relacionou os nomes dos recorrentes a esquemas fraudulentos de taxímetros, a indenização chegou a 50 salários mínimos vigentes em 2004 (cerca

\footnotetext{
${ }^{10}$ Registro feito sobre o tema por Alexandre de Moraes "Honra e ofensas em campanhas eleitorais: STF - 'Crime contra a honra e discussão político-eleitoral: limites de tolerância. As discussões políticas, particularmente as que se travam no calor das campanhas eleitorais renhidas, são inseparáveis da necessidade de emissão de juízos, necessariamente subjetivos, sobre qualidades e defeitos dos homens público nelas diretamente envolvidos, impondo critério de especial tolerância na sua valoração penal, de modo a não tolher a liberdade de crítica, que os deve proteger; mas a tolerância há de ser menor, quando, ainda que situado no campo da vida pública ou da vida privada de relevância pública do militante político, o libelo do adversário ultrapassa a linha dos juízos desprimorosas para imputação de fatos mais ou menos concretos, sobretudo, se invadem ou tangenciam a esfera da criminalidade' (STF - Pleno - Inq. n ${ }^{\circ}$ 503/RJ - questão de ordem - Rel. Min. Sepúlveda Pertence, Diário da Justiça Seção I, 26 mar. 1993, p. 5.001, v.u.). No mesmo sentido: STF - Pleno - Inq. n 496/DF, Rel. Min. Ilmar Galvão, Diário da Justiça, Seção I, 12 nov. 1993, p. 24.022, v.u.; STJ - $1^{\text {a }}$ Seção - Câmara Cível no $22 / \mathrm{PR}$ - Rel. Min. José de Jesus Ementário STJ, n 1/167)" (Moraes, 2005, p. 225/226).
} 
de R\$ 13.000,00); no REsp. 771.377 (Quarta Turma), cuja matéria de fundo dizia respeito a publicações ofensivas à honra de promotor de justiça, foi determinado o pagamento de $\mathrm{R} \$ 35.000,00$ a título de danos morais; no REsp 296.391 (Quarta Turma), em que se tratava de ofensas mútuas de adversários políticos, entendeu a Corte pelo valor de $\mathrm{R} \$ 84.000,00$ àquele que se excedeu em suas manifestações." (STJ. Recurso Especial $n^{\circ}$ 1.169.337/SP, Rel. Ministro Luis Felipe Salomão, Brasília, 18 nov. 2014).

\subsection{3. - "Violência institucional” aos jornalistas}

A partir do Relatório de Liberdade de Imprensa de 2014, elaborado pela ONG Repórteres sem Fronteiras, Mello (2016, p. 71) narra casos de repressão a jornalistas alvos de "violência institucional" pelo contínuo ajuizamento de ações judiciais, que recebem amparo no judiciário.

Para os fins propostos nesse trabalho, os casos mencionados foram escolhidos por terem ambos os jornalistas se manifestado favoravelmente ao direito de resposta.

Um dos casos é o do jornalista Lúcio Flávio Pinto, que responde por mais de trinta ações judiciais (entre cíveis e criminais), em virtude de denunciar ilegalidades praticadas por poderosos na Amazônia. Em nota ao público, expôs:

"Desde 1992 sou submetido a tenaz perseguição por três herdeiros das Organizações Romulo Maiorana, um dos maiores impérios de comunicação do país, com uma emissora de televisão, líder em audiência, afiliada à Rede Globo". ${ }^{11}$

\section{E prossegue:}

"Com a inusitada circunstância de que os donos de tal empresa jamais enviaram ao suposto ofensor uma única carta, no exercício do direito de resposta, nem utilizam seus poderosos veículos de comunicação para contrapor seus argumentos e informações, que são apontados como a causa da ida aos tribunais, caso realmente buscassem a verdade e em respeito à opinião pública. A motivação tornou-se evidente a quem acompanha esse longo percurso de mais de 20 anos: acabar com a existência do Jornal Pessoal, pequena publicação alternativa, pobre de meios, mas que resiste em circulação há 25 anos, denunciando ilicitudes e ilegalidades praticadas por poderosos na Amazônia". ${ }^{12}$

\footnotetext{
${ }^{11}$ Disponível em <https://somostodoslucioflaviopinto.wordpress.com/2013/01/25/nota-aopublico-de-lucio-flavio-pinto/>. Acesso em 28 jun. 2018.

${ }^{12}$ Disponível em <https://somostodoslucioflaviopinto.wordpress.com/2013/01/25/nota-aopublico-de-lucio-flavio-pinto/>. Acesso em 28 jun. 2018.
} 
Após ser condenado ao pagamento de $\mathrm{R} \$ 30.000,00$ (trinta mil reais), divulgou que:

\begin{abstract}
"o valor da indenização imposta pelo juiz equivale a um ano e meio de receita bruta do jornal. Aplicá-la significaria acabar com a publicação, o principal objetivo por trás dessas demandas judiciais a que sou submetido desde 1992. Além de conceder a indenização requerida pelos autores para os supostos danos morais que teriam sofrido por causa da matéria, o juiz me proibiu de voltar a me referir não só ao pai dos irmãos Maiorana, mas a eles próprios, extrapolando dessa forma os parâmetros da própria ação". ${ }^{13}$
\end{abstract}

Também foi condenado ao pagamento de $\mathrm{R} \$ 8.000,00$ (oito mil reais) por ter chamado de "pirata fundiário" empresário responsável por ações de "grilagem" e fraude na Amazônica. Mais tarde, a Polícia Federal comprovou a "grilagem", mas o crime já estava prescrito ${ }^{14}$.

Outro alvo foi o jornalista Luiz Carlos Azenha. Inconformado com a parcialidade da cobertura das eleições feita pela Organizações Globo, demitiu-se e fundou o blog independente "Vi o Mundo". Ao fazer críticas ao jornalista da Globo Ali Kamel, foi condenado ao pagamento de $\mathrm{R} \$ 30.000,00$ (trinta mil reais) (Mello, 2016, p. 74/75). Após, expôs em entrevista:

\begin{abstract}
"o campo de disputa com a grande imprensa é desigual. E eles nos puxam para dentro do campo jurídico, que é onde somos vulneráveis. É óbvio que o Ali Kamel não quer discutir política comigo. Se ele discutir ele perde porque sabe que eu vi as coisas acontecendo dentro da emissora, eu tenho testemunhas. Ele não quer fazer disso em uma discussão política (...) Na discussão política ele foi derrotado completamente. Então ele leva para o campo da discussão judicial, onde ele é uma pessoa privada, mas conta com o apoio da maior emissora da América Latina. E esta judicialização não acontece só comigo. É um fenômeno que está se propagando contra os formadores de opinião da rede. É a Globo, os prefeitos e políticos em geral que vão para este campo. Tivemos um blogueiro que foi assassinado em São Luís do Maranhão. Existem situações em que você é, por não ter dinheiro, sufocado na justiça. Diante da diferença de poder econômico, o poderoso arrasta você pra dentro do campo em que ele tem vantagem. A judicialização é uma decisão política que tem como objetivo sufocar vozes dissidentes, os processos contra os blogs são decisões políticas com o
\end{abstract}

\footnotetext{
${ }^{13}$ Disponível em <http://blogflanar.blogspot.com.br/2009/07/lucio-flavio-pinto-comentasentenca.html>. Acesso em 28 jun. 2018

${ }^{14}$ Disponível em <https://knightcenter.utexas.edu/pt-br/blog/00-12731-censura-togada-ocaso-do-jornalista-lucio-flavio-pinto-e-o-assedio-judicial-no-brasil $\rangle$ $<$ https://www.revistaforum.com.br/jornalista-paraense-e-novamente-condenado-a-pagarindenizacao-exorbitante-a-empresario/>. Acesso em 28 jun. 2018.
} 
objetivo de intimidá-los. Se a intenção fosse debater política, poderia ser exigido o direito de resposta."15

Os casos por supracitados, revelam uma estratégia das grandes corporações de, por meio de ações judiciais (e com possibilidade de êxito), dissuadirem os pequenos jornalistas de exercerem livremente seu direito à manifestação.

15 Disponível em <https://www.sul21.com.br/noticias/2013/04/luiz-carlos-azenhaprocessos-contra-blogs-sao-decisoes-politicas-com-o-objetivo-de-intimidar/>. Acesso em 28 jun. 2018. 


\section{CAPÍTULO 2 - Direito de resposta}

\section{1 - Introdução}

O direito de resposta é estabelecido no plano constitucional desde a Constituição de 1934 e, no plano infraconstitucional, foi regulado pela Lei de Imprensa (art. 16 do decreto $\mathrm{n}^{\mathrm{o}} 4.743$, de 31 de outubro de 1923) em vigor até 2009, quando o Supremo Tribunal Federal a revogou pela ADPF n ${ }^{\circ} 130$.

Atualmente, é previsto no artigo 5º inciso V da Constituição de 1988 e no artigo 14 do Pacto de San José da Costa Rica, referendado pelo Congresso Nacional em novembro de 1992. É regulado na Lei $\mathrm{n}^{\mathrm{o}}$ 13.188/2015 (“dispõe sobre o direito de resposta ou retificação em matéria divulgada, publicada ou transmitida por veículo de comunicação social") e em relação ao direito de resposta no âmbito eleitoral na Lei $\mathrm{n}^{\circ}$ 9.504/1997, em seus artigos 58 e 58-A.

Apesar de sua longa existência no plano formal, "parece ser ainda um direito estranho à nossa realidade, um direito que parece ocupar um lugar secundário na resolução de conflitos entre a liberdade de expressão e o direito à honra e à imagem" - excluindo seu exercício no âmbito eleitoral (Leite, 2018, p. 2).

Considerando o cenário brasileiro, apontado no subcapítulo 1.1 “onde não há regras, não há jurisprudência, não há compromissos prévios, e nem um esforço nesse sentido, tanto pelo Poder Judiciário como pela própria doutrina" (Leite, 2018, p. 4) - e o possível efeito silenciador das condenações civis impostas nesse cenário (subcapítulo 1.2); nesse capítulo a proposta é abordar o direito de resposta como um instrumento potencial e possivelmente mais vantajoso para resolução dos conflitos entre liberdade de expressão e direitos da personalidade do que uma indenização civil, buscando apontar as principais diferenças entre esta e o direito de resposta.

\section{2 - Conceito e funções do direito de resposta}


O conceito do direito de resposta não encontra muita divergência na doutrina, sendo definido como

\begin{abstract}
"trata-se de facultar ao interessado a possibilidade de reagir, riposar, responder, nos meios de comunicação social, às notícias, referências ou imputações que lhe tenham sido feitas. O direito de resposta é um direito derivado. Supõe necessariamente uma notícia ou referência anterior.” (Moreira, 1994, p. 13).
\end{abstract}

"qualquer imputação feita, ofensiva ou prejudicial, atribuindo a outrem atos, fatos ou mesmo circunstancias capazes de magoar, molestar ou mesmo em face de notícias atribuídas a outrem com inverdade ou incorreção 'nasce' o direito de resposta" (Fiorillo \& Ferreira, 2017, p. 116).

Basicamente, aquele "atingido pela publicização de uma informação, notícia ou opinião, tem direito, de pronto, de requerer perante a pessoa ou órgão responsável o exercício do seu direito de resposta" (Germano, 2011, p. 126/127), sendo sua aplicação possível independentemente de legislação ordinária $^{16}$ (Fiorillo \& Ferreira, 2017, p. 108).

O direito de resposta pode ser sintetizado em duas ideias afins, mas distintas: em sentido restrito, representa o direito de corrigir informações inverídicas e, em sentido amplo, representa a possibilidade do interessado apresentar sua versão acerca das acusações, opiniões ou juízos de valor feitas a sua pessoa (Vital Moreira, 1994, p. 13). ${ }^{17}$

\footnotetext{
16 "Garantido o direito, impõem-se a existência de lei que estabeleça a forma de exercê-lo; normal que, por si só, não significa restrição à liberdade de expressão, nela compreendida a liberdade de imprensa. O próprio Min. Celso de Mello (...) não vê empecilho à liberdade de imprensa na existência da lei especifica sobre a matéria, antes a entende adequada. Diz: 'É que esse direito de resposta/retificação não depende, para ser exercido, da existência de lei, ainda que a edição de diploma legislativo sobre essa tema específico possa revelarse útil e, até mesmo, conveniente' (RE no 683.751-RS, Rel. Min. Celso de Mello.) negritei" (Barreto, 2018, p. 23).

${ }^{17}$ Sobre a vulnerabilidade da diferença entre fatos/verdade e opiniões/juízos de valor: "A veracidade dos fatos nunca é forçosamente verdadeira. Os historiadores sabem como é vulnerável a textura de fatos no qual passamos nossa vida cotidiana; está sempre em perigo de ser perfurada em mentiras comuns, ou ser estraçalhada pela mentira organizada de grupos, classes ou nações, ser negada e distorcida, muitas vezes encoberta cuidadosamente por camadas de falsidade, ou ser simplesmente deixada cair no esquecimento. Os fatos necessitam de testemunho para serem lembrados e de testemunhas de confiança para se estabelecerem, para que possam encontrar um abrigo seguro no domínio dos assuntos humanos. Disto decorre que nenhuma afirmação fatual pode estar além da dúvida - tão
} 
Seu principal objetivo é "corrigir uma informação equivocada ou apresentar uma posição discordante da que fora divulgada, quando esta referir o nome ou atos atribuídos a determinada pessoa, física ou jurídica" (Germano, 2011, p. 131), permitindo ao agravado dar sua versão pessoal dos fatos (Moreira, 1994, p. 13).

Vital Moreira indica que esse direito surgiu como um meio de compensar o desequilíbrio entre o cidadão e os titulares dos meios de informação:

\begin{abstract}
"a liberdade de imprensa tornou-se cada vez menos uma faculdade individual de todos, passando a ser cada vez mais um poder de poucos. Hoje em dia, os meios de comunicação de massa já não são expressão da liberdade e autonomia individual dos cidadãos, antes revelam dos interesses comerciais e ideológicos de grandes organizações empresariais, institucionais ou de grupos de interesse. Agora torna-se necessário defender não só a liberdade da imprensa mas também a liberdade face à imprensa. (...) Por isso, pode-se dizer com razão que o direito de resposta surge como um contrapeso da liberdade de imprensa e do poder da imprensa (Blin/Chavanne/Drago, 1969: 56). O direito de resposta perfila-se como um meio de compensar o desequilíbrio natural entre os titulares dos meios de informação - que dispõem de uma posição de força pela posse de um instrumento capaz de incidir substancialmente sobre a opinião pública (Lax, 1989a: 4) - e o cidadão isolado e inerme perante eles. O direito de resposta revela justamente da divisão entre os detentores e os não detentores do poder informativo e visa conferir a estes um meio de defesa perante aqueles" (Moreira, 1994, p. 9/10).
\end{abstract}

Há duas dimensões do direito de resposta: individual e plural. A primeira é a possibilidade

\footnotetext{
"que assiste a todo aquele que seja pessoalmente afectado por notícia, comentário ou referência saída num órgão de comunicação social, de fazer publicar ou transmitir nesse mesmo órgão, gratuitamente, um texto seu contendo um desmentido, rectificação ou defesa" (Moreira, 1994, p. 10).
}

Já a segunda, a dimensão plural, é a que permite "a sociedade (e a cada um dos seus integrantes) a conhecer uma nova perspectiva dos fatos narrados e difundidos que contradizem o conteúdo expressado pelo agravante" (Germano, 2011, p. 196).

segura e protegida contra ataques como, por exemplo, a afirmação de que dois e dois são quatro." (Arendt, 1999, p. 16). 
Considerando o caráter da resposta de permitir "relativizar os discursos unilaterais, possibilitando ao intérprete uma dicotomia capaz de estimular não apenas a reflexão, mas o próprio diálogo" (Germano, 2011, p. 136), ignorar o direito de resposta equivale a “conferir caráter inquestionável a pronunciamentos, notícias e informações, como se o contraditório não pudesse ser exercido" (Germano, 2011, p. 138). Conforme manifestado pelo Ministro Menezes Direito, ao justificar a inconstitucionalidade da Lei de Imprensa: "o preço do silêncio para a saúde institucional dos povos é muito mais alto do que o preço da livre circulação de ideias" (Germano, 2011, p. 179).

Alguns autores veem o direito de resposta como uma limitação à liberdade da imprensa, mas, segundo Vital Moreira, o que é limitado com o direito de resposta é o modo e a gestão do meio de comunicação, e não a liberdade dos jornalistas e responsáveis de escreverem e publicarem o que quiserem (Moreira, 1994, p. 18/19).

No mesmo sentido, se manifesta o Ministro Celso de Mello, no Recurso Extraordinário n 683.751: “A A autonomia editorial, a seu turno, seria preservada desde que seja consignado que a versão ou comentário é de autoria de um terceiro e não representa a opinião do veículo de comunicação"18.

Se o conceito de liberdade de imprensa adotado for que a imprensa "encontra antídoto suficiente na concorrência e no livre mercado das ideias", de forma absoluta, o direito de resposta, nessa concepção de liberdade de imprensa, infringe o editorial (ou seja, a liberdade de gestão do meio de comunicação) e, depois, poderia causar um efeito inibitório no tratamento informativo de determinados assuntos (Moreira, 1994, p. 21). Por outro lado,

"nos países onde vigora o direito de resposta, o entendimento da liberdade de
imprensa não envolve esta ilimitada dimensão proprietarista do poder de exclusão
absoluta do acesso por parte de outrem, nem prevalece essa concepção de
soberania absoluta (Barron, 1992: 3 ) do editor sobre o jornal. Tal como em

${ }^{18}$ Supremo Tribunal Federal, Recurso Extraordinário n ${ }^{\circ}$ 683.751, Rel. Min. Celso de Mello, Brasília, 24 jun. 2015. 
relação ao direito de propriedade em geral, a propriedade dos meios comunicação, por maioria de razão, pode justificar e reclamar obrigações a favor de terceiros e da comunidade em geral. E à medida que se concentra a sua propriedade e diminui o número dos seus detentores, mais justificável se torna alguma forma de socialização do seu uso, como veículo de garantia do direito individual de expressão e informação, pelo menos lá onde tal for requerido para defesa dos direitos de personalidade, quando atacados nos media. Nas palavras de um autor, a liberdade de informação é um direito que não pertence apenas aos meios comunicação, mas também ao público (Loffler, 1974: IV.2)" (Moreira, 1994, p. 22/23).

Desse modo, a "garantia que a resposta a ser exercida pelo legitimado possa ser tão ampla quanto à notícia ou informação que ele pretenda contrapor" (Germano, 2014, p. 77) considera a liberdade de imprensa como "uma via de duas mãos: de um lado, o direito de quem informa; de outro, o interesse (que pode ser até mesmo jurídico) de quem é informado" (Germano, 2014, p. 82) e, assim, "um direito não apenas daqueles que a exercem, mas também da sociedade destinatária das informações pela mídia patrocinadas." (Germano, 2014, p. 88)

Quanto à possível limitação à liberdade de opinião e de crítica (principalmente literária e artística), Vital Moreira afirma que "o direito de resposta não constitui um limite da liberdade de opinião e de crítica, antes estabelece um direito ao contrário por parte da pessoa visada" (Moreira, 1994, p. 23).

Na redação inicial do artigo $8^{\circ}$ da atual Lei que regulamenta o direito de resposta, foi previsto no projeto de lei, em uma das hipóteses em que seria negada a publicação ou transmissão da resposta ou retificação, aquela "VI que tenha por objeto: a) a crítica literária, teatral, artística, científica ou desportiva, salvo se esta contiver calúnia, difamação ou injúria" (Barreto, 2018, p. 168). Contudo, a redação final do artigo $8^{\circ}$ acabou adotando fórmula genérica, sem apresentar hipóteses, mesmo que exemplificativas, de negativa do direito de resposta, cabendo então

"ao veículo de comunicação, na via extrajudicial, e ao Poder Judiciário, na via judicial, analisar a pertinência do pedido ante a matéria tida como ofensiva ou inverídica, ainda que em mero exame perfunctório se descortine a inviabilidade do pleito" (Barreto, 2018, p. 171) 
O mesmo dispositivo constitucional que prevê o direito de resposta prevê também a possibilidade de indenização por dano material, moral e/ou à imagem. Contudo, apesar de previsto no mesmo inciso, são institutos diferentes porque:

"o direito de resposta prescinde da carga probatória exigida para a caracterização do dano material, moral ou à imagem. Enquanto o agravo exigido para o pedido e o consequente exercício do direito de resposta se fundamenta na necessidade de contrapor um fato, notícia ou opinião que foram publicizados (de maneira restrita ou ampla), os danos a que faz menção a parte final do inciso $\mathrm{V}$ do art. $5^{\circ}$ da Constituição encontram-se regulamentados pelo Código Civil, pendendo, no caso de seus reconhecimentos, o arbitramento da indenização por parte do magistrado, nos autos de um processo judicial, ou mediante acordo entre as partes. Seja como for, o certo é que não se está diante de novas modalidades de dano material, moral ou à imagem, mas diante de um mecanismo facilitador do processo de reparação" (Germano, 2011, p. 169/170).

O direito de resposta dispensa alguns dos requisitos necessários para a configuração da responsabilidade civil, tais como (a) o animus injuriandi; (b) a existência de um dano passível de indenização pecuniária; (c) culpa do emitente do pensamento $^{19}$; (d) prova da veracidade da resposta (Germano, 2011, p. 167, 127 e 151); e (e) demonstração da falsidade da notícia (com alguma divergência ${ }^{20}$ ):

"Se a mentira caracteriza crime contra a honra, cujas espécies estão previstas nos artigos 138 e seguintes do Código Penal brasileiro, para fins do que aqui se estuda é insignificante. Evidentemente que a uma notícia ou opinião mentirosa tem o seu grau de ofensa à honra, podendo ensejar a responsabilização penal, civil e, em sendo o caso, até administrativa. Todavia, a divulgação de fato ou informação verdadeira não afastam o direito de resposta, pois tal garantia constitucional não

\footnotetext{
${ }^{19}$ A dispensa de culpa, inclusive, foi indicada no $\S^{\circ}$ do artigo $2^{\circ}$ da Lei $n^{\circ} 13.188 / 2015$, pois considera como objeto passível de direito de resposta a matéria que "atente, ainda que por equívoco de informação, contra (...)". Assim, "esta cláusula está a indicar que não é exigido dolo ou culpa na conduta do ofensor, admitindo-se o direito de resposta ainda que a ofensa decorra de culpa, ou no dizer da lei, por equívoco de informação" (Barreto, 2018, p. 45).

${ }^{20}$ Em sentido contrário, citando Paulo Lúcio Nogueira "não há que se admitir direito de resposta se verdadeira a notícia divulgada" (Barreto, 2018, p. 33), bem como julgados de tribunais de diversos estados colacionados por Barreto nesse mesmo sentido (2018, p. 57/64). De todo modo, a questão não é pacífica "Razões para o não atendimento do pedido extrajudicial. Resposta vaga imprecisa. '(...) - Embora não seja absoluto, o exercício do direito de resposta não está condicionado à prévia demonstração do erro ou inverdade da notícia. (...)' (TACRIM/SP, Ap. no 337.697, $3^{\text {a }}$ Câmara, v.u., j. 13.09.1983, Rel. Dante Busana - JTArim 77/276" (Barreto, 2019, p. 140).
} 
exige a falsidade ou a dissimulação para o seu exercício. O agravo previsto, enquanto elemento do dispositivo constitucional, não tem origem apenas na mentira, na incorreção, no dolo ou na má-fé. O agravo também pode surgir da exposição de um fato verdadeiro, o qual seja atentatório à dignidade humana, tal como a divulgação de uma doença ou de uma situação vexatória (aqui entendida aquela que expõe a pessoa ao ridículo). Aliás, a verdade pode ser mais nociva do que a própria mentira, dependendo do que se divulga e a forma como se publiciza" (Germano, 2011, p. 170/171).

Uma explicação "unifuncional" para o direito de resposta pode ser insuficiente, como adverte Vital Moreira, por vislumbrar, nesse instituto, uma pluralidade de funções, tais como (a) "defesa dos direitos de personalidade", pois "permite à pessoa visada num órgão de comunicação social defender o seu bom nome ou reputação ou outros valores pessoais"; (b) "direito individual de expressão e de opinião", na medida em que é "um direito individual de acesso aos meios de informação"; (c) "instrumento de pluralismo informativo", sendo esta uma função não primária, mas sim sua consequência, pois, apesar da resposta estimular o debate, sua existência exige uma anterior manifestação do órgão, ou seja, depende da agenda do órgão de informação 21 ; e (d) "sanção sui generis ou indemnização em espécie"22, ressaltando que o direito de resposta dispensa tanto a existência de um dano quanto a de um ato ilícito e que "a experiência mostra que na maior parte das vezes o lesado prescinde da acção de indemnização depois de exercido o direito de resposta" (Moreira, 1994, p. 25/32).

\footnotetext{
21 "O pluralismo informativo é garantido fundamentalmente através do pluralismo externo, em que as correntes de opinião se exprimem em distintos órgãos de informação, e do pluralismo interno, na medida em que ele seja um opção do próprio órgão de comunicação social, ou seja um resultado de imposição constitucional ou legal (o que só pode ocorrer em relação aos meios de comunicação públicos). Podem ser variados os meios de dar expressão ao pluralismo interno (cartas dos leitores, tribunas livres, colaborações externas, debates entre representantes de distintas correntes de opinião). O direito de resposta é apenas um desses meios e a sua função primária não é essa. É evidente que o exercício do direito de resposta tem como resultado contribuir para o enriquecimento da informação, através do confronto de duas versões e de dois pontos de vista. (...) Porém, essa não é sua função primária, mas sim uma consequência. Ao responder, o interessado não é um representante do interesse público no pluralismo da informação. (...) Se o interesse principal do direito de resposta fosse o fomento da descentralização e do pluralismo informativo, então toda e qualquer pessoa deveria ter direito de resposta e rectificação e não apenas quem seja visado numa notícia de imprensa." (Moreira, 1994, p. 29).

22 "O direito de resposta não é uma sanção, é um mecanismo de defesa" (Germano, 2011, p. 165).
} 
Para os fins propostos nesse trabalho ganha especial importância o último ponto, considerando a capacidade do direito de resposta de evitar eventual ação indenizatória e, consequentemente, seus possíveis efeitos prejudiciais (subcapítulo 1.2).

Apesar do direito de resposta não prejudicar a ação indenizatória,

"o direito de resposta, mesmo se não prejudica juridicamente as acções de injúria ou de indemnização, na realidade permite frequentemente evita-lás. E de qualquer modo é um instrumento que dispensa o recurso ao tribunal, a contratação de advogado, os incómodos e as despesas inerentes, que só por si deixariam quase sempre sem reacção a maior parte das referências injuriosas ou danosas publicadas, se não houvesse o direito de resposta. Por último, não tendo de limitar-se às referências atentatórias da honra e da consideração, o direito de resposta permite uma defesa mais ampla do que qualquer sistema de proteção penas ou de indemnização poderia oferecer.” (Moreira, 1994, p. 33).

Quanto às suas possíveis consequências, é apontado que "a sua simples existência pressiona os meios de comunicação no sentido de controlarem suas fontes e de se moderarem na imputação de factos pessoas inverídicos ou ofensivos." (Moreira, 1994, p. 33).

Além disso, diferente da procedência de uma ação de indenização, o deferimento da divulgação da resposta

"permite que aquele que teve a sua honra violada se manifeste, trazendo algum equilíbrio, ainda que pontual, no exercício do direito à informação. Além disso, o direito de resposta atinge o público, ou seja, não se trata apenas do direito de o ofendido se manifestar, mas do direito do público de ter acesso ao conteúdo dessa manifestação. No caso acima, por exemplo, a juíza ganhou 150 mil reais, mas o público não ganhou absolutamente nenhuma informação, o que seria importante para formar um juízo mais adequado quanto aos fatos. Por fim, se a condenação em caso de abuso no exercício da liberdade de expressão ou de imprensa pode ter um efeito pedagógico, isso é mais real no direito de resposta do que na indenização, que, aliás, parece ter um efeito pedagógico bastante contestável (seja pelos valores pecuniários que a grande imprensa pode perfeitamente suportar, seja pela própria indefinição do direito brasileiro - doutrina e jurisprudência quanto ao que é lícito ou ilícito nesse tema).” (Leite, 2018, p. 11)

\section{3 - Requisitos para a concessão ou não do direito de}


Germano aponta como requisitos gerais para o exercício do direito de resposta (a) ofensas diretas ou indiretas; ou (b) fatos inverídicos ou incorretos. Não é necessário haver prejuízo, bastando haver equívoco na informação publicizada (Germano, 2011, p. 145).

Como ressaltando supra, a Lei $\mathrm{n}^{\circ} 13.188 / 2015$, deixou de indicar quais casos seriam incabíveis o direito de resposta, adotando fórmula genérica (Barreto, 2018, p. 168/170).

Contudo, de forma geral, Germano indica hipóteses em que o sistema constitucional não abarcaria a resposta, quais sejam: quando a resposta (a) não tem relação direta com o escrito; (b) quando é desproporcional ao texto, tamanho ou tempo que foi utilizado em relação ao que se pretende responder; (c) quando contém expressões detrimentosas, prejudiciais; (d) quando sua publicação atinge terceiros e pode ensejar responsabilidade civil ou penal; e (e) quando é intempestiva, postulada em período distante da notícia ou informação que se pretenda contrapor ou retificar (Germano, 2011, p. 149/152).

No mesmo sentido, Barreto colaciona julgados reiterando alguns dos entendimentos acima: (a) quando a resposta contém "expressões ofensivas ao órgão de informações", "com sentimento revanchista"; (b) "ofensa a terceiros"; e (c) não guarda "relação com matéria incriminada"23. Acrescenta ainda outras razões utilizadas para a negação do pedido de direito de resposta, tais como: (d) quando a publicação advém de "conteúdo de inquérito policial ou boletim de ocorrência" ou de "procedimento administrativo"; (e) "resposta vaga e imprecisa"; e (f) "reprodução de entrevista em jornal" (Barreto, 2018, p. 137/141 e 171).

\footnotetext{
${ }^{23}$ Um julgado citado por Barreto onde é considerado que a resposta extrapola os limites legais: "Pela leitura do pedido de resposta formulado pelo autor observa-se que ele não está apenas esclarecendo ou explicando alguns fatos narrados pelo jornalista da ré, mas está, como se fosse um novo artigo seu, falando de sua pessoa, suas opiniões e ideias e, novamente, apresentando críticas a Reinaldo Azevedo. O acolhimento do pedido do autor, nos termos formulados, não atingiria o objetivo da lei (permitir a defesa do ofendido), mas incentivaria a divergência entre os dois articulistas (...)' (São Paulo-Foro Regional de Pinheiros, $4^{\mathrm{a}}$ Vara Cível, Juiz Paulo Jorge Scartezzini Guimarães, DJSP 29.09.2016, p. 2468)" (Barreto, 2018, p. 174).
} 
Cabe ainda dizer que é estranho ao Poder Judiciário exercer "atividade censora", "cortando" o texto apresentado pelo requerente da resposta e deferindo parcialmente o pedido (Barreto, 2018, p. 146).

$\mathrm{Na}$ via judicial, para requerer o pedido de direito resposta é necessário o requerente provar, na inicial, a negativa do pedido amigável (artigo $3^{\circ}$ da Lei 13.188/2015).

\section{4 - Conceito de "matéria"}

A Lei no 13.188/2015, ao definir o conceito de "matéria", dispõe:

“Artigo $2^{\circ}(\ldots) \S^{\circ}$. Para os efeitos desta Lei, considera-se matéria qualquer reportagem, nota ou notícia divulgada por veículo de comunicação social, independentemente do meio ou da plataforma de distribuição, publicação ou transmissão que utilize, cujo conteúdo atente, ainda que por equívoco de informação, contra a honra, a intimidade, a reputação, o conceito, o nome, a marca ou a imagem de pessoa física ou jurídica identificada ou passível de identificação.".

Veículo de comunicação (ou meio de comunicação social) pode ser definido como:

"conforme explicam Rabaça/Barbosa é o 'o canal (todo suporte material que veicula uma mensagem de um emissor a receptor, através do espaço e do tempo) ou cadeia de canais que liga a fonte (entendida como nascente de mensagens e iniciadora do ciclo de comunicação como ensina James Thompson) ao receptor (que se entende como um dos protagonistas do ato de comunicação: aquele a quem se dirige a mensagem; aquele que recebe a informação e a decodifica, ou seja, transforma os impulsos físicos (sinais) em mensagem recuperada). Sistema (constituído por elementos físicos) onde ocorre a transmissão de mensagens'. Assim todo e qualquer sistema aonde venha a ocorrer a transmissão do 'objeto da comunicação' ou ainda, num sentido mais amplo, todo e qualquer sistema onde se verifica 'o que 'passa' de significativo de comunicação entre emissor e receptor' passa a submeter no âmbito infraconstitucional, em regra, ao império da lei 13.188/15." (Fiorillo \& Ferreira, 2017, p. 120/121).

O conceito de matéria então abrange

"toda publicação impressa constante em jornais, tabloides, revistas, livros, além de matéria transmitida por veículo de comunicação social, como a televisão, o 
rádio, inclusive as rádios comunitárias, previstas na Lei $\mathrm{n}^{\circ}$ 9.612/1998 regulamentada pelo Decreto no 2.614/1998” (Barreto, 2018, p. 30).

Inclusive: (a) "os jornais de bairro, de empresas, de associações de moradores, de sindicatos, de entidades de classe" (Barreto, 2018, p. 30); (b) formas não escritas como "por meio de charge, fotografia, imagem, especialmente estas duas que podem ser editadas e transmitir uma versão inexata dos fatos" (Barreto, 2018, p. 44); (c) "diretamente, se for o caso, como em sua assembleia, por exemplo" (Fiorrilo \& Ferreira, 2017, p. 112); e (d) "Internet, também como meio de comunicação, se presta a divulgar fatos inverídicos, ofensas, etc. que ensejam o direito de resposta" (Barreto, 2018, p. 47).

Além disso, a referência no $\S^{\circ}$ do artigo $2^{\circ}$ da Lei $n^{\circ} 13.188 / 2015$ à “qualquer reportagem, nota ou notícia", seria meramente exemplificativa, podendo ser também objeto do direito de resposta “"nota pública', 'nota de esclarecimento', declaração à praça', etc.” (Barreto, 2018, p. 44).

O $\S 2^{\circ}$ do artigo $2^{\circ}$ da Lei $n^{\circ} 13.188 / 2015$ excluiu do conceito de matéria "os comentários realizados por usuários da internet nas páginas eletrônicas dos veículos de comunicação social". Essa teria sido uma “indesejável limitação ao direito constitucional de resposta, vez que matéria, como ensinam os especialistas, tem definição técnica bem mais ampla" e é indicado que, por limitar garantia constitucional, esse parágrafo seria "ao que tudo indica inconstitucional" (Fiorillo \& Ferreira, 2017, p. 121, 123 e 130).

Registre-se que a imunidade aos autores dos comentários não se estende ao conceito de "compartilhamento", posto que

"conforme anotou o i. Des. Beretta da Silveira em voto vencido na apelação $\mathrm{n}^{\circ}$ 1000159-36.2016.8.26.0366, TJSP, citando a r. sentença recorrida: '(...) 'compartilhamento' de informações se consubstancia em retransmissão do agravo original, possibilitando o acionamento direto daquele que o retransmitiu, conforme permissivo insculpido no artigo $3^{\circ}, \S 1^{\circ}$, da Lei $n^{\circ} 13.188 / 2015^{\prime \prime}$ (Barreto, 2018, p. 51).

Além dos comentários de terceiros, a lei não se aplicaria "às publicações feitas por meio de folhetos, boletins, faixas, outdoors, 
informativos ou congêneres" (Barreto, 2018, p. 31), de modo que exclui do conceito de "matéria" formas que, em tese, poderiam ensejar direito de resposta.

Fiorrilo e Ferreira indicam duas concepções mais amplas que a lei teria excluído no conceito de "matéria" adotado, quais sejam:

"a. no jornalismo como 'tudo que é publicado, ou feito a ser publicado, por jornal, revista, rádio - jornal ou telejornal, incluindo textos e ilustrações (visuais e sonoras). Tanto o original de qualquer notícia, artigo, crônica, etc. quanto sua forma imprensa recebem genericamente, o nome de matéria' e

b. na editoração/artes gráficas como 'qualquer tipo de original (textos, ilustrações, etc) que integra uma publicação (livro, folheto, revista ou qualquer obra imprensa para divulgação; texto informativo ou propagandístico, que se tornou público através de um veículo impresso)"” (Fiorillo \& Ferreira, 2017, p. 123).

Germano, por exemplo, de forma ampla, indica que "quaisquer formas através das quais se expressam ideias, palavras e sentidos, podem dar ensejo ao direito de resposta" (Germano, 2011, p. 168), considerando

\begin{abstract}
"veículos de comunicação deve ser entendido, para os fins aqui pretendidos, como todos os meios através dos quais se publicizam opiniões e manifestações diversas, tais como jornais, revistas, outdoors, programas de rádio e televisão, cinema, blogs, sites, impressos de circulação ampla ou restrita, divulgação de fatos ou informações em murais, palestras, conferências, pronunciamentos, sermões em missa ou cultos etc.” (Germano, 2011, p. 91.).
\end{abstract}

\title{
2.5 - As partes
}

\subsection{1 - Polo ativo}

\section{Quanto à legitimidade para requerer o direito de resposta}

\footnotetext{
"A lei anterior tinha redação mais clara em relação à legitimidade para pleitear direito de resposta ou retificação. Dispunha o art. 29 da Lei $n^{\circ}$ 5.250/1967 que 'Toda pessoa natural ou jurídica, órgão ou entidade pública, que for acusado ou ofendido em publicação feita em jornal o periódico, ou em transmissão de radiofusão, ou a cujo respeito os meios de informação e divulgação veiculam fato inverídico ou, errôneo, tem direito a resposta ou retificação. A lei em comento usou a expressão ‘ofendido' para sintetizar a pessoa física (natural) ou jurídica de direito privado ou de direito público" (Barreto, 2018, p. 34).
} 
Assim,

"quanto à pessoa natural nenhuma dúvida existe, porquanto será aquela explícita ou implicitamente referida na matéria jornalística. Mesmo que não nomeada, a pessoa pode ser identificada pelas referências constantes da publicação, creditando-se, assim, no direito de responder ou de retificar as afirmações ofensivas ou inverídicas.' Sendo a pessoa natural capaz e estando no País, terá legitimidade para requerer o direito de resposta. Tratando-se de ofendido incapaz, falecido ou ausente do País ou de pessoa jurídica, serão representados nos termos do art. $3^{\circ}, \S 2^{\circ}$, inciso II" (Barreto, 2018, p. 35).

Quanto à possibilidade do termo "ofendido" abarcar ou não uma coletividade de pessoas e assim ser aplicado ao direito de resposta coletivo, Barreto defende que seria cabível, porque

\begin{abstract}
“a Constituição garante o direito não apenas ao indivíduo. Assim, não há restrição a que o direito de resposta seja exercido em defesa de segmentos sociais ou de alguma coletividade atingida em sua honra ou contra quem se levantam apontamentos inverídicos. Atingindo a matéria ofensiva ou inverídica um número indeterminado de pessoas, caracterizando o interesse difuso, abre-se a possibilidade do exercício da garantia constitucional por aqueles que são legitimados por lei à defesa dos interesses metaindividuais. Embora tradicional se tenha cuidado do direito de resposta como direito individual, a própria Lei $\mathrm{n}^{\circ}$ 13.188/2015, como acontecia na anterior, não impende se considere 'ofendido' um segmento social ou uma coletividade. O único problema é compatibilizar a legitimidade para a ação e o procedimento a ser adotado" (Barreto, 2018, p. 37).
\end{abstract}

Em relação ao problema citado por Barreto ao final, quanto à legitimidade e procedimento a ser adotado para pleitear o direito de resposta coletivo, o mesmo entende ser possível adotar "medida integrando-se a Lei que regulamenta o direito de resposta com a Lei de Ação Civil Pública (Lei $\left.n^{\circ} 6.347 / 1985\right)$, na seguinte forma:

"adota-se a Lei de Ação Civil Pública para temas como cabimento da ACP; legitimidade, competência, tutela pleiteada e, quanto aos demais, como a obrigação do pedido amigável ou extrajudicial como condição da via judicial, o prazo de decadência, a tutela antecipada, a forma de prestação da obrigação de fazer, etc., aplica-se a Lei do Direito de Resposta" (Barreto, 2018, p. 38).

A título exemplificativo, segue ementa do Agravo de Instrumento em Ação Civil Pública movida pela Defensoria Pública do Estado do Rio de 
Janeiro em face do Secretário de Estado buscando, em um dos pedidos, direito de resposta em razão de declarações do então Secretário a favor da chamada "cura gay". A tutela antecipada para que fosse concedido o direito de resposta antecipadamente foi indeferida por não ter sido vislumbrado o perigo de demora. Contudo, segue ementa do voto vencido julgando procedente a tutela antecipada:

"VOTO VENCIDO. Ação Civil Pública interposta pela Defensoria Pública em face do agravante, sob o argumento de que este, na qualidade de Secretário de Estado de Assistência Social e Direitos Humanos, em entrevista prestada ao jornal "O Globo", informou acreditar na "cura gay", atacando uma das bandeiras da própria Pasta. Decisão agravada que deferiu o pedido de antecipação de tutela, para que seja assegurado o correspondente direito de resposta. Agravante que alega que a demanda se originou com base em uma notícia mentirosa, fruto de hermenêutica perversa do repórter, já que em nenhum momento comparou o comportamento de gays, lésbicas, travestis e transgêneros a qualquer doença, ao contrário, sua conduta sempre foi pautada no respeito à diversidade. Para o deferimento do pedido de antecipação dos efeitos da tutela, não podem ser desprezados os requisitos elencados no artigo 300 do Código de Processo Civil, ou seja, juízo de probabilidade do direito e o perigo de dano ou o risco ao resultado útil do processo, e a verificação da inexistência de perigo de irreversibilidade do provimento antecipado. No caso concreto, observa-se que as matérias jornalísticas, acostadas aos autos principais $\left(\mathrm{n}^{\circ}\right.$ 005209980.2016.8.19.0001), conjugadas as declarações proferidas em sua própria rede social, evidenciam a probabilidade do direito autoral. É público e notório que a homossexualidade não consiste em qualquer tipo de doença e, dessa forma, não pode ser considerada como algo a ser curado, como externou o agravante, através da entrevista concedida ao jornalista, ainda na qualidade de pessoa pública, ocupante de cargo político, declaração que foi posteriormente ratificada na sua própria rede social. Configurado também o risco ao resultado útil do processo, considerando a necessidade iminente de ser reparado o abalo emocional das pessoas alvejadas pelas declarações e ideias do réu, amplamente propagadas na mídia e em sua rede social, na medida em que acarretam impactos no cotidiano do indivíduo, e na segregação da sociedade. Cumpre esclarecer que inexiste perigo de irreversibilidade do provimento antecipado, porque este não possui o condão de esgotar o objeto da demanda, já que o autor requereu ainda a condenação do réu ao pagamento de indenização por danos morais, bem como na obrigação de divulgar o inteiro teor da sentença judicial ao fim do processo. Logo, preenchidos os requisitos do artigo 300 do Código de Processo Civil, deve ser mantida a Decisão que concedeu a antecipação de tutela, revogado o efeito suspensivo recursal - Desprovimento do Agravo de Instrumento." (TJ-RJ. AI n ${ }^{\circ}$ 0057314-40.2016.8.19.0000, voto vencido, Rel. Des. Camilo Ribeiro Rulière, Rio de Janeiro, 07 de fev. 2018).

\subsection{2 - Polo passivo}


O polo passivo do pedido de resposta é o "responsável pelo veículo de comunicação e não àquele que transmitiu a notícia ou fez os comentários ofensivos ao ofendido, pois deste não há como exigir a publicação ou divulgação da resposta" (Barreto, 2018, p. 79).

Também poderá o requerente "agir contra todos os veículos que trouxera a público a matéria ofensiva ou inverídica" (Barreto, 2018, p. 80).

Excepcionalmente, "se o veículo de comunicação social não for constituído sob a forma de pessoa jurídica (ex: blog na internet), neste caso a ação deverá ser ajuizada contra a pessoa física responsável por ele" (Cavalcante, 2016, não paginado).

\section{6 - Diferenças do direito de resposta eleitoral}

Nesse subcapítulo, o objetivo é discorrer brevemente sobre o direito de resposta eleitoral, especialmente quanto à competência dele e do direito de resposta na Justiça Comum, este sendo o objeto do presente trabalho.

Primeiramente, registra-se que o direito de resposta ser aplicável às campanhas políticas é considerado "sistema atípico no panorama internacional" (Steibel, 2006, p. 58) ${ }^{24}$.

Feita essa escolha política, a competência da Justiça Comum é deslocada para a Justiça Eleitoral "a partir da escolha de candidatos em convenção", sendo cabível quando o candidato, partido ou coligação são atingidos por "conceito, imagem ou afirmação caluniosa, difamatória,

\footnotetext{
24 "Tradicionalmente, o Direito de resposta é aplicável somente aos órgãos de imprensa mas, no Brasil, ao contrário de outras democracias como a americana, inglesa, francesa ou argentina, ele é aplicável também às campanhas políticas. (...) O desejo de controlar o nível de informação das campanhas televisivas é um problema frequente em diversas democracias. Várias são as reclamações sobre a imprecisão das propostas políticas apresentadas, o baixo nível de competição entre os candidatos, o uso malicioso de trucagens e montagens de imagens para interferir na interpretação do texto. Porém, poucas democracias optaram por controlar tal 'desequilíbrio' com o auxílio de um órgão judicial" (Steibel, 2006, p. 57/58).
} 
injuriosa ou sabidamente inverídica" (artigo 58, caput da Lei n ${ }^{\circ}$ 9.504/199725, conhecida como Lei das Eleições).

Brevemente, quanto à informação caluniosa, difamatória ou injuriosa, exclui-se a crítica política, englobando somente "o ataque pessoal, que pretenda desqualificar o indivíduo" (Abreu, p. 235). Contudo,

"A linha divisória entre crítica e ofensa repousa num argumento fechado: críticas são políticas e ofensas são pessoais. Porém, visto que o tribunal admite que as campanhas questionem a personalidade do adversário quanto a temas políticos, e que muitas vezes temas políticos se confundem com seus autores (como a corrupção), a linha divisória entre os dois pólos torna-se difusa, obrigando o tribunal a julgar caso a caso.” (Steibel, 2006, p. 90).

Quanto aos "fatos sabidamente inverídicos", é considerado "toda informação inverídica, evidente ou maquiada, desde que prejudique candidato, partido, coligação ou até mesmo terceiros" (Abreu, p. 237).

25 “Art. 58. A partir da escolha de candidatos em convenção, é assegurado o direito de resposta a candidato, partido ou coligação atingidos, ainda que de forma indireta, por conceito, imagem ou afirmação caluniosa, difamatória, injuriosa ou sabidamente inverídica, difundidos por qualquer veículo de comunicação social.”. 


\section{CAPÍTULO 3 - Tratamento dado ao direito de resposta pelo Tribunal de Justiça do Estado do Rio de Janeiro (2016-2018)}

\section{1 - Objetivos}

O objetivo geral desse capítulo é identificar como o direito de resposta tem sido compreendido nos casos levados ao judiciário, especificamente quanto aos pontos citados no capítulo 1 e 2 , quais sejam (a) se costuma ser deferido o direito de resposta conjuntamente com indenização civil ou não, nos casos em que ambos foram pedidos; e (b) quais os requisitos considerados nas decisões para a concessão ou negativa do direito de resposta.

Além disso, o objetivo também é buscar trazer exemplos concretos e dados quantitativos que permitam compreender de forma mais clara e objetiva o instituto.

\section{2 - Metodologia da pesquisa}

Foram levantadas as decisões judiciais do Tribunal de Justiça do Estado do Rio de Janeiro no período de 2016 a 09 de julho de 2018, através do site do próprio Tribunal ${ }^{26}$, filtrando os resultados pelo termo de busca "direito de resposta", data (2016 a 2018), origem "Tribunal de Justiça do Rio de Janeiro 2a Instância", competência "cível", incluindo "acórdão" e "decisão monocrática".

Registre-se que o site do Tribunal de Justiça do Estado do Rio de Janeiro só busca o termo de referência ("direito de resposta") através do trecho da ementa (e não do interior teor da decisão).

\section{3 - Análise dos resultados}

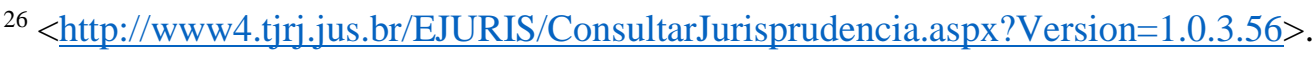




\subsection{1 - Dados quantitativos dos resultados}

Foram encontrados 53 resultados, dos quais 30 foram excluídos por (a) não ter sido pedido especificamente o direito de resposta, sendo apenas citado na ementa; (b) tratar do cumprimento de sentença; (c) agravos de instrumentos (seja de tutela antecipada, os quais tratavam dos requisitos para a sua concessão, seja de cumprimento de sentença, etc.); (d) tratar sobre conflito de competência com a justiça eleitoral, que não é objeto do presente trabalho; (e) gratuidade; (f) irregularidade na representação processual; (g) ação cautelar; (h) acolherem prejudicial de mérito (prescrição); enfim, objetos estranhos aos objetivos aqui pretendidos (subcapítulo 3.1).

Dos 23 resultados pertinentes com os objetivos desse trabalho, dez concederam o direito de resposta, um anulou a sentença e os demais (doze) negaram o pedido de resposta, cujos principais motivos serão analisados, respectivamente, nos subcapítulos 3.3.2 e 3.3.3.

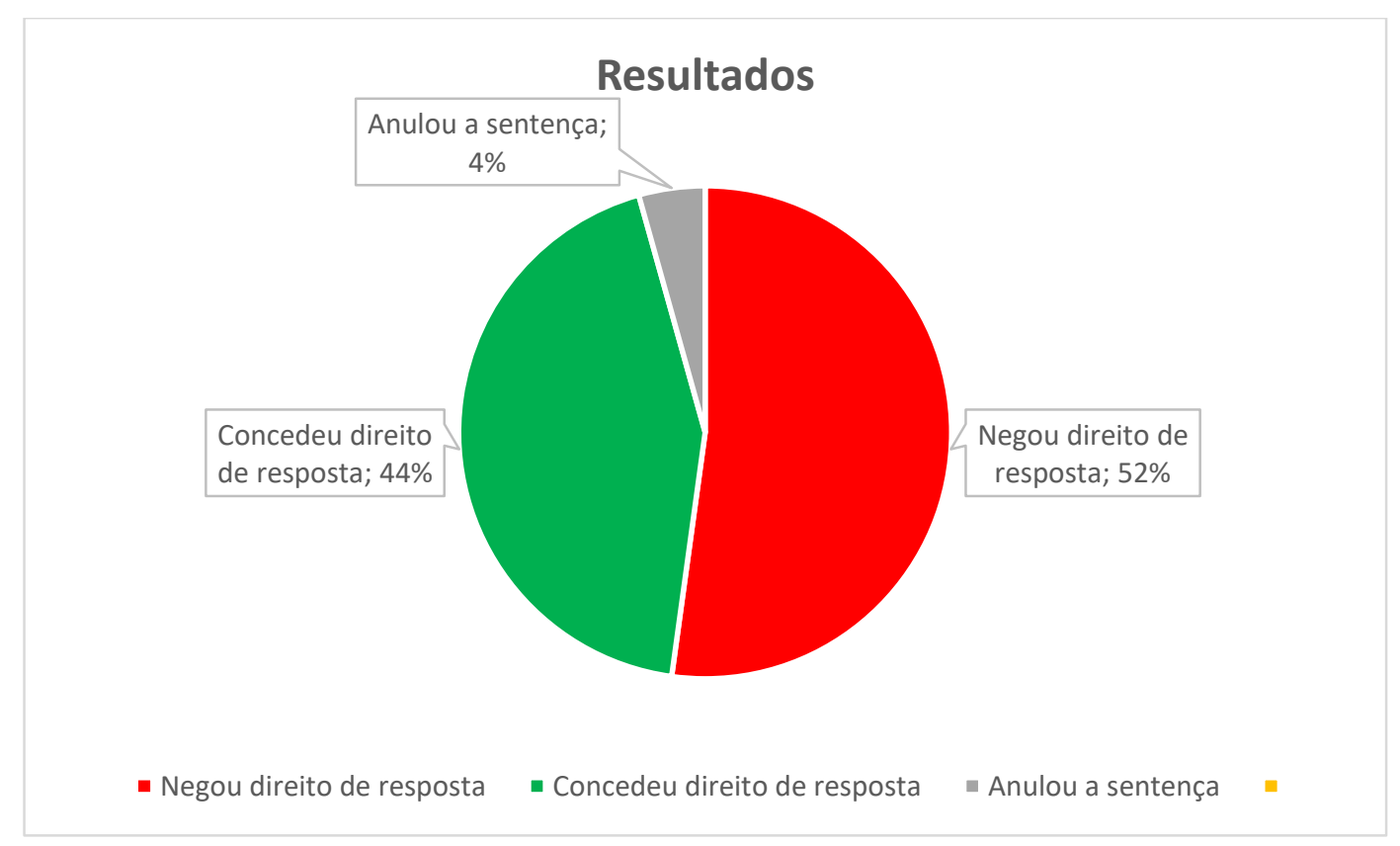

Dos 23 resultados, em sete deles a indenização não foi incluída no rol dos pedidos (lembrando que isso não obsta ação própria para isso). Dos 
18 casos em que foram pedidos ambos (a) em apenas um deles foi concedido somente direito de resposta; (b) em apenas um deles foi concedido somente indenização; (c) em oito foram concedidos os dois; e (d) em seis foram negados os dois.

Por fim, dos 25 resultados, 7 reformaram a sentença em relação ao direito de resposta e o restante manteve a decisão de $1^{\circ}$ grau - relacionada ao deferimento ou não do direito de resposta.

\subsection{2 - Apontamento dos principais fundamentos para a concessão do direito de resposta}

Dos dez casos em que foi concedido o direito de resposta, quatro deles foi por haver erro ou equívoco na notícia, quais sejam: (a) “Tornou-se incontroverso que tal informação não corresponde à verdade dos fatos (...) amplo esclarecimento no meio social quanto ao equívoco da informação divulgada" (TJ-RJ, AC nº 0009376-06.2013.8.19.0210, Rel. Des. Fernando Cerqueira Chagas, Rio de Janeiro, 08 jan. 2017) 27 28; (b) “condenou as rés a publicarem notícia, nos mesmos moldes da ofensiva, comunicando o erro" (TJ-RJ, AC nº 0019930-07.2008.8.19.0038, Rel. Des. Gabriel de Oliveira Zefiro, Rio de Janeiro, 07 jun. 2017)"29; (c) "foi atribuído ao autor o fato inverídico de que seria o responsável pela emissão da ordem" 30 (TJ-RJ, AC

\footnotetext{
${ }^{27}$ Caso tratava de matéria divulgando que o autor teria sido levado preso à Delegacia e chamando-o de "baderneiro", "meliante", quando na verdade foi à Delegacia porque havia sido chamado como testemunha dos eventos.

${ }^{28}$ Foi ainda assentado que "a honra e a imagem dos cidadãos não são violadas quando se divulgam informações verdadeiras a seu respeito e que, sobretudo, são de interesse público" (TJ-RJ, AC no 0009376-06.2013.8.19.0210, Rel. Des. Fernando Cerqueira Chagas, Rio de Janeiro, 08 jan. 2017).

${ }^{29}$ Divulgação falsa de que a autora da ação teria morrido por dengue.

${ }^{30}$ Nesse caso, houve voto vencido, julgando improcedentes os pedidos, porque "policiais da própria UPP, que ratificaram a informação de que havia ordem nesse sentido por parte do comandante, possibilitando, inclusive, acesso à cópia da determinação em questão, documento esse que ostenta timbre do Governo do Estado e da Polícia Militar"; "não se podendo negar que, de fato, referido documento foi redigido sem obedecer às regras mínimas de concordância, de forma imprecisa, imperfeita, do ponto de vista da melhor escrita"; concluindo que "atos divulgados não retratam ofensa à honra e imagem pessoal do apelado, tratando-se de reportagem de cunho informativo, sem qualquer caráter
} 
no 0036262-29.2014.8.19.0203, Rel. Des. Jaime Dias Pinheiro Filho, Rio de Janeiro, 20 mar. 2018); (d) "a matéria apresentou uma imprecisão no valor divulgado como salário percebido pelo autor" (TJ-RJ, AC nº 009285687.2014.8.19.0001, Rel. Des. André Gustavo Corrêa de Andrade, Rio de Janeiro, 27 jan. 2016) - nesse caso a sentença, apesar de reconhecer o erro, indeferiu o direito de resposta diante da "idoneidade da origem da informação e do informante" (16 ${ }^{a}$ Vara Cível da Comarca Central do Rio de Janeiro, Processo $\mathrm{n}^{\circ}$ 0092856-87.2014.8.19.0001, juíza Adriana Sucena Monteiro Jara Moura, Rio de Janeiro, 08 mai. 2015) ${ }^{31}$ - todas as citações sem grifos nos originais.

Outro fator considerado foi "o fato público e notório do apoio dispensado pelo primeiro autor a líder político alvo de investigações e processos criminais não significa que a ele também devem ser imputados os mesmos crimes. O comentário perpetrado pelo réu, assim, se encontra

\section{desprovido de qualquer base probatória ou mesmo de notícia a respeito}

do tema, configurando ofensa e violação à honra daquela família" (TJ-RJ, AC n 0024592-47.2016.8.19.0001, Rel. Des. Norma Suely Fonseca Quintes, Rio de Janeiro, 30 jan. 2018) ${ }^{32}$ - grifei.

depreciativo ou difamatório à pessoa do autor" (TJ-RJ, AC n ${ }^{\circ}$ 0092856-87.2014.8.19.0001, voto vencido, Rel. José Acir Lessa Giordani, Rio de Janeiro, 27 jan. 2016).

${ }^{31}$ Segue trechos da sentença: "O réu, baseando-se em informação de funcionária da Câmara dos Vereadores, teve conhecimento do suposto salário do autor que seria de $\mathrm{R} \$ 7.100,00$ (sete mil e cem reais), quando o provado pelo autor seria de pouco mais de $\mathrm{R} \$ 800,00$ (oitocentos reais), um equívoco apenas quanto ao valor do salário do autor, haja vista, o autor ser realmente funcionário da Câmara dos Vereadores, que não enseja a configuração de dano moral. A idoneidade da origem da informação e do informante, não reclamavam maior cuidado na apuração da verdade, configurando animus narrandi." $\left(16^{\mathrm{a}}\right.$ Vara Cível da Comarca Central do Rio de Janeiro, Processo $\mathrm{n}^{\circ}$ 009285687.2014.8.19.0001, juíza Adriana Sucena Monteiro Jara Moura, Rio de Janeiro, 08 mai. 2015).

${ }^{32}$ Registre-se que o "comentário" foi "XINGAMENTO POSTADO NO PERFIL DOS AUTORES NA REDE SOCIAL 'INSTAGRAM"” e a condenação foi "A PUBLICAÇÃO DE PEDIDO DE DESCULPAS PELO RÉU NÃO AFASTA O DEVER DE INDENIZAR. 5. INDENIZAÇÃO INSUFICIENTEMENTE ARBITRADA. MAJORAÇÃO PARA R \$20.000,000 PARA CADA AUTOR QUE SE IMPÕE. 6. IMPOSTA OBRIGAÇÃO DE FAZER CONSUBSTANCIADA NA PUBLICAÇÃO DA SENTENÇA EM DOIS JORNAIS DE GRANDE CIRCULAÇÃO, BEM COMO NA REDE SOCIAL INSTAGRAM. DIREITO DE RESPOSTA PREVISTO NO ART. $5^{\circ}, \mathrm{V}$, DA CR/88 E NO ART. 2 ${ }^{\circ}$, DA LEI N. ${ }^{\circ} 13.188 / 2015 . "$ (TJ-RJ, AC nº 0024592-47.2016.8.19.0001, Rel. Des. Norma Suely Fonseca Quintes, Rio de Janeiro, 30 jan. 2018) 
Em um caso envolvendo divulgação da imagem de um cidadão, associando-o a atividade criminosa, houve divergência nos julgamentos de $1^{\mathrm{o}}$ e $2^{\mathrm{o}}$ grau. $\mathrm{O}$ colegiado julgou procedente $\mathrm{o}$ direito de resposta, considerando

\begin{abstract}
"o autor afirma que nunca respondeu a processo criminal e após prestar os devidos esclarecimentos aos policiais, foi liberado, sem que houvesse qualquer associação do seu nome com o traficante "Negueba" e seus comparsas. (...) o autor, funcionário de um supermercado, logrou comprovar que sua imagem foi exposta publicamente como criminoso capturado com armas e drogas (fls. 3638). Atenta-se, além disso, que os graves fatos imputados ao autor, foi levado a conhecimento público, sem possibilidade do exercício do direito de defesa" (TJRJ. AC n ${ }^{\circ}$ 0008884-19.2015.8.19.0024, Rel. Des. Elton Martinez Carvalho Leme, Rio de Janeiro, 14 mar. 2018).
\end{abstract}

Pelas considerações indicadas acima, os desembargadores concluíram que a matéria atribuindo ao autor a prática de ilícito penal seria uma conduta ilícita do veículo de comunicação que enseja o direito de resposta (e indenização por dano moral).

Em $1^{\mathrm{a}}$ instância, por outro lado, havia sido indeferido o pedido de resposta. O juízo considerou que as informações seriam verdadeiras e amparadas em opiniões prestadas pelas autoridades públicas responsáveis pela investigação

\footnotetext{
"verifica-se que o Autor se envolveu no episódio retratado pelo jornal, ora Réu nesta demanda. O Autor não refutou o fato em si, nem poderia, porquanto encontrava-se, de fato, na companhia de elementos que portavam armas, munições, jóias e determinada quantidade de dinheiro que, certamente, era fruto de atividade ilícita. Veja-se que a Ré, em tais publicações, não citou os nomes do autor e de seu amigo Wendel, resumindo-se a mencionar, como suspeitos, apenas os nomes daqueles que os mesmos alegam terem os abordado (Negueba, Jhonatan e Alan), como se observa às fls. 36. Assim, não há dúvidas de que o fato narrado era verdadeiro, tendo apenas o jornal colocado a foto do réu como um dos suspeitos de prática do crime, sem contudo afirmar sua efetiva autoria. Assim, em realidade, em que pese a imagem do autor ter constado das referidas reportagens, não se verificou qualquer citação de seu nome, muito menos vinculando-o ao fato em si ou the atribuindo responsabilidade. Assim, tem-se que não ocorrida qualquer ofensa a sua honra, como ora quer fazer acreditar. Assim, vê-se que não se pode reconhecer o dano moral em razão do próprio fato no caso posto, uma vez que o jornalista não extrapolou no atuar de sua profissão o dever de informar, atendo-se a fatos verdadeiros, informações e opiniões prestadas pelas autoridades públicas responsáveis pela investigação. (...) não restou comprovado que o Réu tenha agido com culpa. As publicações não foram
} 
ofensivas e representam a exteriorização do direito de informação, inerente à atividade jornalística, não havendo exagero na notícia. Ademais, não logrou êxito a parte autora em demonstrar eventual prejuízo gerado pelas referidas publicações, sendo certo que as mesmas não mencionaram seu nome. Valendo ressaltar, ainda, que caberá ao juízo competente aprofundar-se na análise do fato e das provas, a fim de verificar se o autor, de fato, naquela oportunidade, não atuava em conluio com todos os outros envolvidos naquela ocasião" $\left(1^{\mathrm{a}}\right.$ Vara Cível da Comarca de Itaguaí, Processo no 0008884-19.2015.8.19.0024, Rio de Janeiro, 26 out. 2015).

Outro caso em que houve divergência entre os julgamentos foi em uma ação movida por agente público, colocado como réu em uma ação popular. A sentença foi reformada para conceder o direito de resposta porque

\begin{abstract}
"restou evidenciada a malícia proposital, ao colocar o nome do apelante entre os 'denunciados', como estando envolvido na 'falcatrua' que diz estar pairando sobre o concurso realizado pela Prefeitura do município (...) A inicial de uma ação popular, portanto, nada mais é do quê a manifestação de um cidadão, segundo suas próprias convicções, não encarnando qualquer pronunciamento de instituições públicas, de modo que os fatos ali imputados a outrem devem ser avaliados pelos veículos de imprensa com as devidas cautelas. Ademais, o apelante foi apenas incluso como réu no processo, o qual tramita, vale salientar, em âmbito civil, não sendo denunciado e não tendo nenhuma "falcatrua" sido constatada." (TJ-RJ, AC n 0050893-85.2014.8.19.0038, Rel. Des. José Roberto Portugal Compasso, Rio de Janeiro, 09 mai. 2017).
\end{abstract}

A sentença julgou em sentido contrário porque a matéria seria verídica. Segue trecho principal da sentença, citado no acórdão:

\begin{abstract}
“o autor é um agente público que ocupa cargo político, não pode esperar privacidade ou reserva sobre o fato de estar respondendo a uma ação popular, o qual é de evidente interesso público. Acrescenta ainda que é lícito informar ao povo tudo que é de interesse público, tendo a matéria publicada apenas retratado um fato verídico, repetindo somente o que consta da Ação Popular, sendo esta pública" (TJ-RJ, AC no 0050893-85.2014.8.19.0038, Rel. Des. José Roberto Portugal Compasso, Rio de Janeiro, 09 mai. 2017).
\end{abstract}

Em uma matéria amparada em vasto conjunto probatório (incluindo decisões judiciais e do Tribunal de Contas) foi reformada a sentença para conceder o direito de resposta, considerando tratar-se de "pessoa e órgão de natureza pública, cuja atividade depende de sua reputação"; "caráter dialético decorrente do exercício do direito de resposta"; e "interesse público manejado". Também por uma imprecisão, "a indigitada matéria teria afirmado que o SENAC-RJ apresentou um déficit de $\mathrm{R} \$ 23,9$ milhões em 
2010, quando, na verdade, houve, muito ao contrário, um superávit de R\$450,6 milhões naquele período"; concluindo que

\begin{abstract}
"diante de tamanha dissonância entre os valores apontados por uma e outra parte deve ser garantida a apresentação ao público da versão dos fatos desejada pelos ora recorrentes, de modo até mesmo a enaltecer e abrilhantar o trabalho jornalístico empreendido pelos recorridos. $\mathrm{O}$ direito de resposta não é o direito a verdade absoluta, é o direito do ofendido de dizer a sua verdade, cabendo aos leitores avaliar e sopesar os elementos da reportagem e, assim, contraditá-la com a versão que não teve acesso ou conhecimento." (TJ-RJ, AC n ${ }^{\circ}$ 022357327.2013.8.19.0001, Rel. Des. Carlos Eduardo Moreira da Silva, Rio de Janeiro, 27 fev. 2018.).
\end{abstract}

A sentença julgou em sentido contrário, por entender que o direito de resposta se presta a corrigir erros, e discussão acerca de ofensa à honra deveria ser tratada em âmbito de indenização civil (que não foi pedida). Seguem os trechos principais da sentença:

\begin{abstract}
"a matéria traz as fontes de todos os dados que divulgou, como indicados na contestação. Tudo o que narra, relativamente a fatos e números, consta de documentos públicos, sejam processos judiciais, sejam procedimentos administrativos. Aponta haver investigações em curso, e relata números e estatísticas financeiras, estes extraídos de documentos oficiais. Está em exercício regular do direito de informar, em respeito à liberdade de imprensa. (...) O que se tem, portanto, é que os autores, tanto as pessoas jurídicas quanto a pessoa física, reputaram ofensivas as alegações, e sentiram-se atingidos em sua honra e reputação. Para remediar estas alegadas ofensas existe o instituto da reparação de danos, pedido não formulado. Não serve, para tanto, o instituto do direito de resposta, que se destina a reparar erros" ( $41^{\mathrm{a}}$ Vara Cível da Comarca Central do Rio de Janeiro, Processo no 0223573-27.2013.8.19.0001, Rio de Janeiro, 11 mai. 2017).
\end{abstract}

Em outro caso em que o alvo é também uma pessoa de natureza pública (servidor público), membro do poder judiciário, acusado da prática de tráfico de influência e corrupção passiva foi concedido o direito de resposta porque "ainda que movida por legítimo juízo de aparência dos fatos e do interesse público", não se tratava de matéria inédita e as investigações ainda estavam em curso na época da publicação (TJ-RJ, AC nº 038175055.2014.8.19.0001, Rel. Des. Pedro Saraiva De Andrade Lemos, Rio de Janeiro, 14 set. 2016). 
No mesmo sentido, mas não sendo pessoa pública, foi concedido o direito de resposta por considerar que as acusações atribuídas pela matéria à autora sequer haviam sido investigadas pelas autoridades competentes:

\begin{abstract}
"verifica-se que a ré extrapolou os limites da simples informação ao expor a imagem dos autores indevidamente, em reportagem televisiva, acusando a segunda autora de maus-tratos a idoso sob o pretexto de informar a sociedade a respeito de um crime não investigado pelas autoridades policiais competentes, instigando a população a se revoltar contra ela. Fica evidente que a matéria veiculada não buscava apenas noticiar atos de maus tratos a idosos, mas expor, irresponsavelmente, a imagem dos envolvidos, acusando a segunda autora de um crime e gerando, com isso, consequências graves e perigosas de agressão e violência (...) a imagem é objeto de direito autônomo, cuja violação configura ofensa à honra e à personalidade, devendo ser admitido, além, da indenização arbitrada, o direito de resposta nos termos estipulados na sentença" (TJ-RJ, AC $\mathrm{n}^{\mathrm{o}}$ 0020495-35.2011.8.19.0209, Rel. Des. Benedicto Abicair, Rio de Janeiro, 06 abr. 2017).
\end{abstract}

\title{
3.3.3 - Apontamento dos principais fundamentos para o indeferimento do direito de resposta
}

Um dos fundamentos vistos foi a inexistência de prejuízo, conforme trecho transcrito da ementa abaixo:

\begin{abstract}
"Ocorre que as manifestações não detêm verdade em si, sendo inconteste e socialmente reconhecida a relevância para a Classe Profissional, não havendo que se falar em ferimento da honra pois as alegações dos réus não possuem fundamento. Ademais, por todo o tempo decorrido da demanda judicial e a rispidez observada nas verbalizações proferidas fica evidente que o infortúnio já se dissipou (ou deveria) diante dos objetivos maiores a que se propõem de um lado, os profissionais da área médica, e, de outro lado, representantes do povo e agentes políticos" (TJ-RJ, AC $\mathrm{n}^{\circ}$ 0092457-10.2004.8.19.0001, Rel. Des. Conceição A. Mousnier, Rio de Janeiro, 20 jun. 2018).
\end{abstract}

Em outro caso, foi decidido que seria necessário "fatos sabidamente falsos", reconhecidos em uma matéria injuriosa, difamatória ou caluniosa, entendida a injúria como a "manifestação gratuita, desconectada de fatos, com o que não se confunde a crítica negativa de comportamentos e práticas reais". Nesse caso especifico, também foi ressaltado que a matéria "utiliza linguagem claramente indicativa de manifestação de opinião sobre figuras e eventos públicos" (grifos no original). Além disso, foi registrado que 
"Sancionar os meios de comunicação por conta da manifestação de opiniões reduziria a liberdade de imprensa ao direito de meramente reproduzir os arquivos públicos, como um Diário Oficial, subtraindo a própria razão de ser da garantia, que é a livre circulação do pensamento e das ideias" (TJ-RJ, AC n ${ }^{\circ} 0004383$ 85.2016.8.19.0024, Rel. Des. Eduardo Gusmão Alves de Brito Neto, Rio de Janeiro, 22 maio. 2018.)

No mesmo sentido do julgado citado, para a concessão do direito de resposta seria necessário "comprovadas erronias ou inverdades publicadas irregularmente". Como a "matéria foi divulgada com isenção e clareza, sem nenhuma informação tendenciosa", seria incabível o direito de resposta. A imparcialidade teria sido demonstrada porque "a própria matéria publicou a versão do autor" (TJ-RJ, AC nº 0295158-08.2014.8.19.0001, Rel. Des. Elton Martinez Carvalho Leme, Rio de Janeiro, 7 mar. 2018).

Outro fator considerado para a negativa da resposta é quando a matéria se limita a noticiar "fatos objetivos" sequer negados pelo autor (apesar do autor requerer seu direito de resposta para complementar os fatos com outras informações ${ }^{33}$ ):

\footnotetext{
"no caso em exame foram noticiados os fatos que motivaram a instauração da sindicância. A existência da sindicância não é negada pelo autor. Por sua vez, o resultado da sindicância ou a ausência de oferecimento de denúncia em desfavor do autor, ao contrário do que afirma em suas razões do apelo, é desinfluente para o deslinde do feito, haja vista a independência entre as instâncias administrativa, cível e criminal. (...) As matérias que envolvem o autor tiveram lastro em fatos objetivos, em gravações de condutas. Tal fato tem relevância social, vez que se trata de notícia de corrupção na Administração Pública. A reportagem tem foco sobre o suposto esquema; quanto ao autor, somente a instauração de sindicância para averiguação de sua participação é que foi noticiada" (TJ-RJ, $\mathrm{AC} \mathrm{n}^{\circ} 0255454-$ 17.2016.8.19.0001, Rel. Des. André Ribeiro, Rio de Janeiro, 08 ago. 2017).
}

\footnotetext{
${ }^{33}$ Como "que a matéria foi divulgada sem qualquer direito de defesa ou contraponto por parte do autor; que foi ignorado o passado funcional do autor, que possui "Moção de Louvor" por parte da Assembleia Legislativa do Estado do Rio de Janeiro, e também "Diploma de Honra ao Mérito" obtido da Secretaria de Estado de Justiça e Interior e do Departamento do Sistema Penitenciário; que o autor nunca foi condenado por crimes; que tal fato viola a saúde psicológica, a moral, a honra e a imagem do autor; que não houve direito de resposta." (TJ-RJ, AC n 0255454-17.2016.8.19.0001, Rel. Des. André Ribeiro, Rio de Janeiro, 08 ago. 2017).
} 
No caso acima, foram considerados "fatos objetivos" em vista das gravações existentes. Também quando a notícia baseou-se em "fontes oficiais" foi negado o direito de resposta ("as reportagens deixaram claro que as informações veiculadas na notícia advieram de fontes oficiais, disponibilizadas pelo Ministério do Planejamento"), superando até o argumento do autor que a matéria seria "tendenciosa e parcial acerca da recomposição da inflação em favor dos servidores do Judiciário Federal", bem como por conter informações inverídicas (segundo o autor):

\begin{abstract}
"Sustenta que a publicação trouxe dados inverídicos sobre o reajuste, sobre o impacto nos cofres públicos e sobre os vencimentos básicos dos servidores, acirrando os ânimos da sociedade contra o reajuste, pelo que são devidos o direito de resposta e a reparação." (TJ-RJ, AC n ${ }^{\circ}$ 0314576-92.2015.8.19.0001, Rel. Des. Pedro Saraiva De Andrade Lemos, Rio de Janeiro, 13 set. 2017)
\end{abstract}

Outro acervo probatório apto a negar o direito de resposta seria

\begin{abstract}
"a matéria questionada fundamenta-se em informações prestadas pelo próprio autor, por pessoas que o auxiliam na condução dos negócios e por terceiros ligados a ele, a seus imóveis e a inúmeras discussões judiciais, além de elementos colhidos diretamente de fontes oficiais e idôneas, como o Tribunal de Justiça deste Estado e a Assembleia Legislativa" (TJ-RJ, AC $\mathrm{n}^{\circ}$ 001933045.2014.8.19.0209, Rel. Des. Luiz Roldao de Freitas Gomes Filho, Rio de Janeiro, 26 abr. 2017).
\end{abstract}

É negado o direito de resposta quando as matérias "correspondiam aos fatos noticiados naquela localidade" (TJ-RJ, AC $\mathrm{n}^{\circ}$ 010506868.2013.8.19.0004, Rel. Des. Maria Regina Nova, Rio de Janeiro, 26 jul. 2016) 34; “MATÉRIAS JORNALÍSTICAS VEICULADAS QUE APENAS NOTICIAM, PRESTANDO INFORMAÇÕES, DEIXANDO DE EMITIR

\footnotetext{
${ }^{34}$ A autora alegava que "Autora relata que a Ré, por meio do "Jornal O São Gonçalo", publicou matéria jornalística de cunho ofensivo, imputando-lhe a prática de fato criminoso, qual seja, o suposto sequestro de sua neta, o que, segundo ela, violou sua intimidade, honra e imagem". Foi decido que: "Em relação à matéria veiculada pela Apelada, seu título veio nos seguintes termos: 'Pais encontram filha de 5 anos 'sequestrada' pelos avós, em SG'. Quanto à palavra 'sequestrada', necessário esclarecer que esta vem entre aspas, justamente para indicar que aquele fato não correspondia à realidade, tanto que no corpo da notícia vinha a exposição correta a respeito do ocorrido, que informava que se "tratava, na verdade, de um descumprimento de decisão judicial'” (TJ-RJ, AC n 0105068-68.2013.8.19.0004, Rel. Des. Maria Regina Nova, Rio de Janeiro, 26 jul. 2016).
} 


\title{
QUALQUER JUÍZO DE VALOR” (TJ-RJ, AC $\mathrm{n}^{\mathrm{o}}$ 0001178-
}

94.2013.8.19.0075, Rel. Des. Eduardo de Azevedo Paiva, Rio de Janeiro, 15 jun. 2016) $)^{35}$ e "informam os fatos, sem juízo de valor quanto aos envolvidos" (TJ-RJ, AC nº 0016828-68.2016.8.19.0014, Rel. Des. José Roberto Portugal Compasso, Rio de Janeiro, 09 mai. 2017) ${ }^{36}$. Informar sobre a existência de investigação, por exemplo, seria o caso:

\begin{abstract}
"Noticiar que foi protocolado pedido de CPI para investigar as referidas obras e relatar sobre a existência de lista envolvendo políticos do Município no recebimento de valores da referida empreiteira, sem menção de que todos teriam recebido os valores de forma ilícita, não é, como alardeado pelo autor, dizer que todos os políticos constantes das listas da referida empreiteira sejam envolvidos em falcatruas investigadas pela operação "Lava Jato", mas informar a população sobre a existência da investigação." (TJ-RJ, AC no 0016828-68.2016.8.19.0014, Rel. Des. José Roberto Portugal Compasso, Rio de Janeiro, 09 mai. 2017)
\end{abstract}

Em outro caso, em que havia "detalhes inverídicos"37 (logo, em princípio, seria cabível o direito de resposta), foi sopesado que esses “detalhes inverídicos” não teriam "conteúdo ofensivo", haja vista a ausência

35 A autora se insurge "pretendendo obter direito de resposta, alegando ter sido indevidamente acusada - através de publicações jornalísticas - de ameaçar a presidente do Sindicato (...) os demandados cometeram abuso no direito de informar, até porque passaram adiante fatos que ainda estavam sendo investigados, tendo caráter sigiloso". Foi decidido que: "Não é possível cogitar em violação a inquérito sigiloso, eis que as matérias veiculadas trataram apenas de informar que a Sra. Presidente do Sindicato dos Servidores Públicos do Município de Magé afirmou ter sido ameaçada pela autora, não tendo aplicação dispositivo da lei penal, ainda que por analogia. Houve pura narração dos fatos, sem qualquer insinuação, o que não é capaz de gerar os transtornos alegados pela autora/apelante, a lhe gerar o pretendido direito de resposta." (TJ-RJ, AC n 0001178-94.2013.8.19.0075, Rel. Des. Eduardo de Azevedo Paiva, Rio de Janeiro, 15 jun. 2016).

${ }^{36}$ Sobre fatos inverídicos: "No título dado a reportagem, de fato, há equívoco, a esposa do autor, como se extrai do conteúdo da notícia não foi considerada ré, não houve recebimento de denúncia, o que houve foi determinação para que o Ministério Público emendasse a inicial incluindo o nome das pessoas a serem investigadas, entre elas a prefeita do Município de Campos. Tal equívoco até que poderia ser corrigido "retificado" com o direito de resposta, contudo, para tanto, o pedido teria de ser formulado pela suposta prejudicada e não pelo autor, vez que a lei 13.188/2015, que regula o exercício do direito de resposta garante tal direito somente ao ofendido" ((TJ-RJ, AC no 0016828-68.2016.8.19.0014, Rel. Des. José Roberto Portugal Compasso, Rio de Janeiro, 09 mai. 2017).

37 "a notícia falsa que trouxe prejuízos à moral do falecido é a parte "Ao saber que teria compromisso inadiável arrancou os tubos. vestiu a roupa e foi para casa, onde morreu de enfarte horas depois"' (TJ-RJ, AC n 0113165-71.2010.8.19.0001, Rel. Des. Denise Nicoll Simões, Rio de Janeiro, 12 set. 2017). 
de "uso indevido do nome"; "imputação criminosa"; ou "circunstância que poderia causar dano à memória":

\begin{abstract}
"apesar da aludida matéria possuir detalhes inverídicos acerca do falecimento de Domberg, não há qualquer caráter ofensivo à reputação do falecido, parente dos Autores. (...) o direito de resposta não está associado ao simples aprimoramento da notícia, à insatisfação com manifestações duras e contundentes ou ao desejo de apresentação de outra versão. Impõe-se que de fato haja informação inverídica ofensiva na reportagem. Assim, não se mostra cabível in casu o deferimento ao pedido de direito de resposta ante a ausência de conteúdo ofensivo: não houve o uso indevido do nome do falecido, imputação criminosa ou circunstância que poderia causar dano à sua memória." (TJ-RJ, AC nº 0113165-71.2010.8.19.0001, Rel. Des. Denise Nicoll Simões, Rio de Janeiro, 12 set. 2017).
\end{abstract}

Outro motivo para negativa do direito de resposta é a desarmonia dos objetivos do direito de resposta com a leitura da íntegra da sentença. Nesses termos, foi negado o direito de resposta e deferida a indenização:

"O direito de resposta foi insculpido, portanto, para cumprir a finalidade específica referida, não sendo toda e qualquer modalidade de resposta que atinge o objetivo constitucional e legal. A leitura da íntegra da sentença ora em análise em programa televisivo somente atingiria o objetivo do direito de resposta se a decisão fosse concisa, sem excesso personalista impertinente à solução do conflito e revestida de objetividade jurídica, de modo a contribuir efetivamente para reparar a imagem pública da autora, sem desviar o foco da demanda e criar mais polêmicas." (TJ-RJ, AC n ${ }^{\circ}$ 0030477-08.2013.8.19.0208, Rel. Des. Elton M. C. Leme, Rio de Janeiro, 22 jun. 2016.).

Em caso tratando de matéria em que autor do livro alegava que a matéria impugnada distorcia os argumentos e as pesquisas feitas em sua dissertação, inclusive atribuindo ao autor atividade de má fé e militância contra a corporação que publicou a nota, foi decido que as críticas seriam esperadas "em obra literária publicada e posta ao público em geral”:

"1. Se por um lado o texto publicado pelos réus tece severa crítica ao livro do ora apelante, com frontal discordância à comparação da Polícia Militar com o pato, por outro, é preciso considerar que a comparação do policial militar com a imagem do pato, pelo sentido pejorativo atribuído ao animal, ainda que não tenha partido do autor, como ele afirma, tomou muito maiores proporções em razão de sua divulgação no livro por ele publicado. 2. Não poderia o apelante, autor de obra literária publicada e posta ao público em geral, esperar e tolerar o recebimento tão somente de elogios, eis que a crítica é esperável de todo aquele 
que publica obra escrita ou assemelhada." (TJ-RJ, AC $\mathrm{n}^{\circ}$ 037475759.2015.8.19.0001, Rel. Des. Gilberto Matos, Rio de Janeiro, 27 set. 2016).

Por fim, o caso em que a sentença foi anulada, foi em demanda em que o presidente de um sindicato pleiteava direito de resposta em nome próprio. Em $1^{\circ}$ instância o processo foi extinto, sem resolução do mérito, por ilegitimidade ativa, pelas seguintes razões

\begin{abstract}
"A Autora ingressou com a presente ação em nome próprio, não sendo possível pleitear direito de terceiro, no caso, o Sindicado que preside. A matéria contra a qual a Autora se insurge diz respeito ao Sindicato e não à pessoa da Autora, que apenas foi mencionada na condição de presidente da entidade. Logo, eventual direito de resposta caberia ao Sindicato e não à pessoa física que o preside.”( $32^{\mathrm{a}}$ Vara Cível da Comarca da Capital do Rio de Janeiro, Processo $\mathrm{n}^{\circ} 0080360$ 26.2014.8.19.0001, Juízo Leonardo Grandmasson Ferreira Chaves, Rio de Janeiro, 06 set. 2017).
\end{abstract}

Em sentido contrário, o colegiado anulou a sentença para "reconhecer a legitimidade ativa da Autora/Apelante para propor a presente demanda, na medida em que seu nome foi mencionado na matéria jornalística veiculada pelo Réu/Apelado" (TJ-RJ, AC n 0080360-26.2014.8.19.0001, Rel. Des. Luciano Saboia Rinaldi de Carvalho, Rio de Janeiro, 18 abr. 2018). 


\section{CONCLUSÕES}

Como visto no capítulo 1, a subjetividade dos parâmetros decisórios, atrelada às condenações civis e valores indenizatórios fixados, permite concluir que, em muitos casos, essas ações civis (ou a possibilidade de) podem funcionar como uma forma de censura (posterior), através da autocensura e do "chilling efect", inibindo ou dificultando a publicação de denúncias políticas, principalmente para os pequenos meios de comunicação, com poucos recursos financeiros.

Apresentado esse problema, no capítulo 2, foi tratado do direito de resposta e mostrado ser possível a condenação em direito de resposta anterior à condenação civil. Aliás, os requisitos para o primeiro são mais simples que os do segundo.

Contudo, como visto no capítulo 3 , dos 18 casos em que foi pedido tanto direito de resposta como indenização, em aproximadamente $90 \%$ dos casos ambos tiveram o mesmo resultado (ou ambos indeferidos ou ambos deferidos).

Comparando o capítulo 2 com o 3, verifica-se que os julgados trazem novos requisitos para conceder o direito de resposta, havendo uma dissonância entre os requisitos apontados pela constituição, pela lei e pela doutrina (capítulo 2) com a amostra dos julgados apresentados no capítulo 3.

Entre as dissonâncias está a doutrina afirmar ser desnecessário prova do prejuízo (aliás, uma diferença em relação à configuração da responsabilidade civil, que exige a presença do dano), enquanto um dos fundamentos levantados nos julgados para justificar o indeferimento do direito de resposta é a ausência de prejuízo ${ }^{38}$.

\footnotetext{
${ }^{38}$ TJ-RJ, AC no 0092457-10.2004.8.19.0001, Rel. Des. Conceição A. Mousnier, Rio de Janeiro, 20 jun. 2018; TJ-RJ, AC n ${ }^{\circ}$ 0113165-71.2010.8.19.0001, Rel. Des. Denise Nicoll Simões, Rio de Janeiro, 12 set. 2017; $1^{\text {a }}$ Vara Cível da Comarca de Itaguaí, Processo $n^{\circ}$ 0008884-19.2015.8.19.0024, Rio de Janeiro, 26 out. 2015.
} 
Em consonância com a doutrina, os julgados utilizam bastante o argumento do equívoco ou a falsidade da notícia ${ }^{39}$. Contudo, esse argumento pode ser relativizado quando as informações da matéria forem coletadas de fontes oficias, como depoimentos de funcionários públicos ${ }^{40}$. A ausência de base probatória no que é veiculado na notícia também é um fundamento utilizado para conceder o direito de resposta ${ }^{41}$, como quando há ainda investigações em curso ${ }^{42}$.

Argumentos novos trazidos pelos julgados foram: (a) necessidade da notícia divulgar "fatos sabidamente falsos" "43; (b) "isenção e clareza" na narrativa, que denotaria imparcialidade da matéria e, portanto, incabível o direito de resposta 44 ; (c) assim como quando narra "fatos objetivos" ou "sem juízo de valor"45; e (d) quando originam-se de "fontes oficiais e idôneas"46.

\footnotetext{
${ }^{39}$ TJ-RJ, AC no 0009376-06.2013.8.19.0210, Rel. Des. Fernando Cerqueira Chagas, Rio de Janeiro, 08 jan. 2017; TJ-RJ, AC n ${ }^{\circ}$ 0019930-07.2008.8.19.0038, Rel. Des. Gabriel de Oliveira Zefiro, Rio de Janeiro, 07 jun. 2017; TJ-RJ, AC no 0036262-29.2014.8.19.0203, Rel. Des. Jaime Dias Pinheiro Filho, Rio de Janeiro, 20 mar. 2018; (TJ-RJ, AC nº 009285687.2014.8.19.0001, Rel. Des. André Gustavo Corrêa de Andrade, Rio de Janeiro, 27 jan. 2016; TJ-RJ. AC n ${ }^{\circ}$ 0008884-19.2015.8.19.0024, Rel. Des. Elton Martinez Carvalho Leme, Rio de Janeiro, 14 mar. 2018; $41^{\mathrm{a}}$ Vara Cível da Comarca Central do Rio de Janeiro, Processo $n^{\circ}$ 0223573-27.2013.8.19.0001, Rio de Janeiro, 11 mai. 2017.

$4016^{\mathrm{a}}$ Vara Cível da Comarca Central do Rio de Janeiro, Processo $\mathrm{n}^{\mathrm{o}}$ 009285687.2014.8.19.0001, juíza Adriana Sucena Monteiro Jara Moura, Rio de Janeiro, 08 mai. 2015; $1^{\text {a }}$ Vara Cível da Comarca de Itaguaí, Processo n ${ }^{\circ}$ 0008884-19.2015.8.19.0024, Rio de Janeiro, 26 out. 2015.

${ }^{41}$ TJ-RJ, AC n ${ }^{\circ}$ 0024592-47.2016.8.19.0001, Rel. Des. Norma Suely Fonseca Quintes, Rio de Janeiro, 30 jan. 2018.

${ }^{42}$ TJ-RJ, AC no 0050893-85.2014.8.19.0038, Rel. Des. José Roberto Portugal Compasso, Rio de Janeiro, 09 mai. 2017; TJ-RJ, AC nº 0381750-55.2014.8.19.0001, Rel. Des. Pedro Saraiva De Andrade Lemos, Rio de Janeiro, 14 set. 2016; TJ-RJ, AC n ${ }^{\circ} 0020495-$ 35.2011.8.19.0209, Rel. Des. Benedicto Abicair, Rio de Janeiro, 06 abr. 2017.

${ }^{43}$ TJ-RJ, AC no 0004383-85.2016.8.19.0024, Rel. Des. Eduardo Gusmão Alves de Brito Neto, Rio de Janeiro, 22 maio. 2018.

${ }^{44}$ TJ-RJ, AC n ${ }^{\circ}$ 0295158-08.2014.8.19.0001, Rel. Des. Elton Martinez Carvalho Leme, Rio de Janeiro, 7 mar. 2018.

${ }^{45}$ TJ-RJ, AC no 0255454-17.2016.8.19.0001, Rel. Des. André Ribeiro, Rio de Janeiro, 08 ago. 2017; TJ-RJ, $\mathrm{AC} \mathrm{n}^{\circ}$ 0105068-68.2013.8.19.0004, Rel. Des. Maria Regina Nova, Rio de Janeiro, 26 jul. 2016; TJ-RJ, AC n ${ }^{\circ}$ 0001178-94.2013.8.19.0075, Rel. Des. Eduardo de Azevedo Paiva, Rio de Janeiro, 15 jun. 2016; TJ-RJ, AC nº 0016828-68.2016.8.19.0014, Rel. Des. José Roberto Portugal Compasso, Rio de Janeiro, 09 mai. 2017.

${ }^{46}$ TJ-RJ, AC no 0019330-45.2014.8.19.0209, Rel. Des. Luiz Roldao de Freitas Gomes Filho, Rio de Janeiro, 26 abr. 2017; TJ-RJ, AC no 0016828-68.2016.8.19.0014, Rel. Des. José Roberto Portugal Compasso, Rio de Janeiro, 09 mai. 2017; 16 ${ }^{\mathrm{a}}$ Vara Cível da Comarca Central do Rio de Janeiro, Processo n ${ }^{\circ}$ 0092856-87.2014.8.19.0001, juíza Adriana Sucena Monteiro Jara Moura, Rio de Janeiro, 08 mai. 2015; $1^{\text {a }}$ Vara Cível da Comarca de Itaguaí, Processo ${ }^{\circ}$ 0008884-19.2015.8.19.0024, Rio de Janeiro, 26 out. 2015.
} 
Quanto ao item (d), sobre as fontes, registre-se, entendimento contrário, que pesou mais por tratar de "órgão público" e, portanto, por haver “interesse público manejado" ${ }^{47}$ ser cabível o direito de resposta - que é outro fundamento não apontando na doutrina, nem na lei (que não diferencia ser pessoa/órgão público). Talvez por isso ele seja utilizado tanto para conceder (como o foi nesse caso) quanto para indeferir o direito de resposta ${ }^{48}$.

Por fim, também foi excluído da possibilidade do direito de resposta a crítica literária ${ }^{49}$ e a publicação ou leitura da sentença ${ }^{50}$. Quanto ao último ponto, registre-se que parece existir um avanço nos julgados do Tribunal de Justiça do Rio de Janeiro, que costumavam condenar o réu a publicar ou ler a íntegra da sentença (mesmo após a revogação da Lei da Imprensa, que previa isso) ${ }^{51}$. É considerado um avanço porque o vocabulário jurídico e técnico da sentença torna o texto inacessível para aqueles que não estão familiarizados com o linguajar jurídico e, portanto, a resposta nesse estilo deixava de atingir sua finalidade, tornando-se mera formalidade.

Conclui-se que o direito de resposta na prática judiciária precisa preencher mais requisitos do que os apontados na Constituição, na lei que regulamenta o direito de resposta e na doutrina.

Além disso, o Tribunal de Justiça do Rio de Janeiro parece estar caminhando no sentido oposto ao defendido no presente trabalho, pois costuma julgar o direito de resposta e a indenização no mesmo sentido,

\footnotetext{
${ }^{47}$ TJ-RJ, AC no 0223573-27.2013.8.19.0001, Rel. Des. Carlos Eduardo Moreira da Silva, Rio de Janeiro, 27 fev. 2018.

${ }^{48}$ Sentença do caso TJ-RJ, AC $\mathrm{n}^{\circ}$ 0050893-85.2014.8.19.0038, Rel. Des. José Roberto Portugal Compasso, Rio de Janeiro, 09 mai. 2017; TJ-RJ, AC $\mathrm{n}^{\mathrm{o}}$ 025545417.2016.8.19.0001, Rel. Des. André Ribeiro, Rio de Janeiro, 08 ago. 2017; TJ-RJ, AC n 0009376-06.2013.8.19.0210, Rel. Des. Fernando Cerqueira Chagas, Rio de Janeiro, 08 jan. 2017.

${ }^{49}$ TJ-RJ, AC n ${ }^{\circ}$ 0374757-59.2015.8.19.0001, Rel. Des. Gilberto Matos, Rio de Janeiro, 27 set. 2016 ${ }^{50}$ TJ-RJ, AC no 0030477-08.2013.8.19.0208, Rel. Des. Elton M. C. Leme, Rio de Janeiro, 22 jun. 2016.

51 "Na prática, e por razões desconhecidas, a publicação de sentença (ou acórdão) acabou adquirindo um status de direito de resposta, e se tornou algo tão enraizado que resistiu, em muitos casos, à própria revogação da lei de imprensa. No âmbito do TJRJ, por exemplo, a publicação de decisão judicial foi imposta em sete apelações cíveis, sendo que seis foram julgadas após a decisão da $3^{\mathrm{a}}$ Turma do STJ (em 15/12/2009), que reconheceu que a publicação de sentença "não se confunde com o direito de resposta, de modo que ele não encontra fundamento direto na constituição federal" (Recurso Especial n. 885.248/MG).” (Leite, 2018, não paginado).
} 
deixando de reconhecer o direito de resposta como condenação anterior à condenação civil e, em alguns casos, atribuindo a dois institutos diferentes os mesmos requisitos. 


\section{BIBLIOGRAFIA}

ABREU, Alessandro Balbi. O direito de resposta na esfera eleitoral sob a ótica da doutrina e da jurisprudência. Disponível em < http://capa.trers.jus.br/arquivos/ALESSANDRO_O direito_de_resposta_pdf >. Acesso em 22 out. 2018.

ARENDT, Hannah. Crises da república. São Paulo: Editora Perspectiva, 1999. $201 \mathrm{p}$.

Associação Nacional de Jornais. Relatório de Atividade e de Liberdade de Imprensa (2014-2016). Disponível em < https://www.anj.org.br/site/relatorios-de-atividade.html>. Acesso em 27 jun. 2018.

ÁVILA, Humberto. Teoria dos princípios: Da definição à aplicação dos princípios jurídicos. 9a edição. São Paulo: Editora Malheiros, 2009. 190 p.

BARRETTO, Carlos Roberto. Direito de resposta: Comentários à Lei $\mathrm{n}^{\circ}$. 13.188/2015. São Paulo: Letras Jurídicas, 2018. 240 p.

BERENGER, Carolina Gonçalves. Os Contornos do Interesse Público à Luz da Jurisprudência nos Casos de Liberdade de Expressão. Rio de Janeiro, 2017. 14 p. Relatório de Pesquisa de Iniciação Científica do Departamento de Direito da PUC-RIO. Disponível em <http://www.pucrio.br/pibic/relatorio_resumo2017/relatorios_pdf/ccs/DIR/DIR-

Carolina\%20Berenger.pdf>. Acesso em 30 set. 2018.

CABRAL, Eula Dantas Taveira. Mídia no Brasil: Concentração das Comunicações e Telecomunicações. Revista Eptic, volume 17, $\mathrm{n}^{\mathrm{o}}$ 3, setembro-dezembro 2015. Disponível

em 
<https://seer.ufs.br/index.php/eptic/article/view/4298/pdf>. Acesso em 12 nov. 2018.

CAVALCANTE, Márcio André Lopes. Comentários à Lei 13.188/2015 (Direito de Resposta). Disponível em <https://www.dizerodireito.com.br/2015/11/comentarios-lei-131882015direito-de.html>. Acesso em 27 set. 2018.

CHEQUER, Cláudio. A liberdade de expressão como direito fundamental preferencial prima facie: Análise crítica e proposta de revisão ao padrão jurisprudencial brasileiro). Rio de Janeiro: Lumes Juris, 2011. 353 p.

Corte Europeia de Direitos Humanos, Linges v. Austria, Strasbourg, 08 jul. 1986

DUARTE, Rachel. Luiz Carlos Azenha: "Processos contra blogs são decisões políticas com o objetivo de intimidar”. Sul 21. 08 abr. 2013. Disponível em <https://www.sul21.com.br/noticias/2013/04/luiz-carlosazenha-processos-contra-blogs-sao-decisoes-politicas-com-o-objetivo-deintimidar/>. Acesso em 28 jun. 2018.

Entrevista com Mônica Iozzi no Programa do Bial. Disponível em <https://www.youtube.com/watch?v=BmOYcO9LHh8>. Acesso em 27 jun. 2018.

FIORILLO, Celso Antonio Pacheco; FERREIRA, Renata Marques. Liberdade de Expressão e Direito de Resposta na Sociedade de Informação. Rio de Janeiro: Lumen Juris, 2017. 176 p.

FRAGA, Isabela. O caso do jornalista Lúcio Flávio Pinto: emblema do assédio judicial no Brasil. Journalism in the Americas. 29 jan. 2013. Disponível em <https://knightcenter.utexas.edu/pt-br/blog/00-12731- 
censura-togada-o-caso-do-jornalista-lucio-flavio-pinto-e-o-assedio-judicialno-brasil>. Acesso em 28 jun. 2018.

GERMANO, Luiz Paulo Rosek. Direito de resposta. Porto Alegre: Livraria do Advogado Editora, 2011. 209 p.

Jornalista Paraense é novamente condenado a pagar indenização exorbitante a empresário. Fórum. 23 jan. 2013. Disponível em $<$ https://www.revistaforum.com.br/jornalista-paraense-e-novamentecondenado-a-pagar-indenizacao-exorbitante-a-empresario/>. Acesso em 28 jun. 2018.

LEAHY, Victor Campos Clement. Liberdade de Expressão e o Controle dos Filmes Ofensivos. Revista da AGU, v. 35, p. 351-382, 2013. Disponível em $<$ https://seer.agu.gov.br/index.php/AGU/article/view/65/56>. Acesso em 24. set. 2018.

LEITE, Fábio Carvalho. Liberdade de Expressão e Direito à Honra: Novas diretrizes para um velho problema. In: Clèmerson Merlin Clève; Alexandre Freire. (Org.). Direitos fundamentais e jurisdição constitucional: análise, crítica e contribuições. $1^{a}$ edição. São Paulo: Revista dos Tribunais, 2014, v., p. 395-408. Disponível em < http://www.academia.edu/26753748/Liberdade de Express\%C3\%A3o e di reito \% C3\% A0 honra_novas diretrizes_para_um_velho_problema>. Acesso em 20 jun. 2017.

LEITE, Fábio Carvalho. Por uma posição preferencial do direito de resposta nos conflitos entre liberdade de imprensa e direito à honra. 2018. Disponível em $\quad$ http://civilistica.com/por-uma-posicao-preferencial-do-direito-deresposta-nos-conflitos-entre-liberdade-de-imprensa-e-direito-a-honra/> . Acesso em 20 set. 2018. 
MARX, Karl. A liberdade de imprensa. Porto Alegre: L\&PM, 1980. 132 p.

MELlO, Rodrigo Gaspar de. Liberdade de Expressão, Honra e Responsabilidade Civil: Uma proposta de adoção da doutrina da malícia real como meio de combate à censura judicial no direito brasileiro. Rio de Janeiro, 2016. 342 p. Tese (Doutorado em Direito) Departamento de Direito da PUCRio.

MELLO, Rodrigo Gaspar de. A Censura Judicial como Meio de Restrição da Liberdade de Expressão: Análise Comparativa da Jurisprudência da Corte Interamericana de Direitos Humanos, da Corte Suprema de Justiça da Nação argentina e do Supremo Tribunal Federal. Rio de Janeiro, 2012. 154 p. Tese (Mestrado em Direito) Departamento de Direito da PUC-Rio.

MORAES, Alexandre de. Constituição do Brasil interpretada e legislação constitucional. São Paulo: Atlas, 2005. 2922 p.

MOREIRA, Vital. O direito de resposta na comunicação social. Coimbra: Editora Coimbra, 1994. 227 p.

PINTO, Lúcio Flavio. Lúcio Flávio Pinto Comenta a sentença. Diversidade de opinião. Belém, 07 jul. 2009. Disponível em <http://blogflanar.blogspot.com.br/2009/07/lucio-flavio-pinto-comentasentenca.html>. Acesso em 28 jun. 2018.

PINTO, Lúcio Flávio. Nota ao público de Lúcio Flávio Pinto. Todos com Lúcio Flávio Pinto. Belém, 25 jan. 2013. Disponível em <https://somostodoslucioflaviopinto.wordpress.com/2013/01/25/nota-aopublico-de-lucio-flavio-pinto/>. Acesso em 28 jun. 2018. 
STEIBEL, Fabio Boas. Propaganda negativa e judicialização da política no horário eleitoral presidencial de 2002. Niterói, 2006. 139 p. Tese (Mestrado em Comunicação) Departamento de Comunicação da Universidade Federal Fluminense.

Supremo Tribunal Federal, Recurso Extraordinário nº 683.751, Rel. Min. Celso de Mello, Brasília, 24 jun. 2015.

TOLLER, Fernando M. O formalismo da liberdade de expressão. São Paulo: Saraiva, 2010. $131 \mathrm{p}$.

Tribunal de Justiça do Estado do Rio de Janeiro, Apelação Cível no 009285687.2014.8.19.0001, Rel. Des. André Gustavo Corrêa de Andrade, Rio de Janeiro, 27 jan. 2016.

Tribunal de Justiça do Estado do Rio de Janeiro, Apelação Cível nº 000117894.2013.8.19.0075, Rel. Des. Eduardo de Azevedo Paiva, Rio de Janeiro, 15 jun. 2016.

Tribunal de Justiça do Estado do Rio de Janeiro, Apelação Cível no 0030477 08.2013.8.19.0208, Rel. Des. Elton M. C. Leme, Rio de Janeiro, 22 jun. 2016.

Tribunal de Justiça do Estado do Rio de Janeiro, Apelação Cível nº 010506868.2013.8.19.0004, Rel. Des. Maria Regina Nova, Rio de Janeiro, 26 jul. 2016.

Tribunal de Justiça do Estado do Rio de Janeiro, Apelação Cível nº 038175055.2014.8.19.0001, Rel. Des. Pedro Saraiva De Andrade Lemos, Rio de Janeiro, 14 set. 2016. 
Tribunal de Justiça do Estado do Rio de Janeiro, Apelação Cível no 0374757 59.2015.8.19.0001, Rel. Des. Gilberto Matos, Rio de Janeiro, 27 set. 2016.

Tribunal de Justiça do Estado do Rio de Janeiro, Apelação Cível nº 0009376 06.2013.8.19.0210, Rel. Des. Fernando Cerqueira Chagas, Rio de Janeiro, 08 jan. 2017.

Tribunal de Justiça do Estado do Rio de Janeiro, Apelação Cível nº 0020495 35.2011.8.19.0209, Rel. Des. Benedicto Abicair, Rio de Janeiro, 06 abr. 2017.

Tribunal de Justiça do Estado do Rio de Janeiro, Apelação Cível nº 0019330 45.2014.8.19.0209, Rel. Des. Luiz Roldao de Freitas Gomes Filho, Rio de Janeiro, 26 abr. 2017.

Tribunal de Justiça do Estado do Rio de Janeiro, Apelação Cível no 0016828 68.2016.8.19.0014, Rel. Des. José Roberto Portugal Compasso, Rio de Janeiro, 09 mai. 2017.

Tribunal de Justiça do Estado do Rio de Janeiro, Apelação Cível nº 0050893 85.2014.8.19.0038, Rel. Des. José Roberto Portugal Compasso, Rio de Janeiro, 09 mai. 2017.

Tribunal de Justiça do Estado do Rio de Janeiro, Apelação Cível no 001993007.2008.8.19.0038, Rel. Des. Gabriel de Oliveira Zefiro, Rio de Janeiro, 07 jun. 2017.

Tribunal de Justiça do Estado do Rio de Janeiro, Apelação Cível nº 025545417.2016.8.19.0001, Rel. Des. André Ribeiro, Rio de Janeiro, 08 ago. 2017. 
Tribunal de Justiça do Estado do Rio de Janeiro, Apelação Cível no 0113165 71.2010.8.19.0001, Rel. Des. Denise Nicoll Simões, Rio de Janeiro, 12 set. 2017.

Tribunal de Justiça do Estado do Rio de Janeiro, Apelação Cível no 031457692.2015.8.19.0001, Rel. Des. Pedro Saraiva De Andrade Lemos, Rio de Janeiro, 13 set. 2017.

Tribunal de Justiça do Estado do Rio de Janeiro, Apelação Cível nº $0024592-$ 47.2016.8.19.0001, Rel. Des. Norma Suely Fonseca Quintes, Rio de Janeiro, 30 jan. 2018.

Tribunal de Justiça do Estado do Rio de Janeiro, Apelação Cível nº 0223573 27.2013.8.19.0001, Rel. Des. Carlos Eduardo Moreira da Silva, Rio de Janeiro, 27 fev. 2018, Rio de Janeiro, 27 fev. 2018.

Tribunal de Justiça do Estado do Rio de Janeiro, Apelação Cível nº 029515808.2014.8.19.0001, Rel. Des. Elton Martinez Carvalho Leme, Rio de Janeiro, 7 mar. 2018.

Tribunal de Justiça do Estado do Rio de Janeiro, Apelação Cível nº 000888419.2015.8.19.0024, Rel. Des. Elton Martinez Carvalho Leme, Rio de Janeiro, 14 mar. 2018.

Tribunal de Justiça do Estado do Rio de Janeiro, Apelação Cível nº $0036262-$ 29.2014.8.19.0203, Rel. Des. Jaime Dias Pinheiro Filho, Rio de Janeiro, 20 mar. 2018.

Tribunal de Justiça do Estado do Rio de Janeiro, Apelação Cível no 008036026.2014.8.19.0001, Rel. Des. Luciano Saboia Rinaldi de Carvalho, Rio de Janeiro, 18 abr. 2018. 
Tribunal de Justiça do Estado do Rio de Janeiro, Apelação Cível nº 0004383 85.2016.8.19.0024, Rel. Des. Eduardo Gusmão Alves de Brito Neto, Rio de Janeiro, 22 maio. 2018.

Tribunal de Justiça do Estado do Rio de Janeiro, Apelação Cível nº $0092457-$ 10.2004.8.19.0001, Rel. Des. Conceição A. Mousnier, Rio de Janeiro, 20 jun. 2018.

Um ambiente de trabalho cada vez mais instável. Repórteres Sem Fronteiras: Pela Liberdade da Informação. Disponível em <https://rsf.org/pt/brasill . Acesso em 27 jun. 2018.

$1^{\mathrm{a}}$ Vara Cível da Comarca de Itaguaí, Processo $\mathrm{n}^{\mathrm{o}} 0008884-$ 19.2015.8.19.0024, Rio de Janeiro, 26 out. 2015.

$16^{\text {a }}$ Vara Cível da Comarca Central do Rio de Janeiro, Processo n ${ }^{\circ} 0092856-$ 87.2014.8.19.0001, juíza Adriana Sucena Monteiro Jara Moura, Rio de Janeiro, 08 mai. 2015.

41 ${ }^{\text {a }}$ Vara Cível da Comarca Central do Rio de Janeiro, Processo n ${ }^{\circ} 0223573$ 27.2013.8.19.0001, Rio de Janeiro, 11 mai. 2017. 


\section{NORMAS PARA ELABORAÇÃO E APRESENTAÇÃo DA MONOGRAFIA}

\section{ANEXO II}

\section{A Monografia deve ser entregue até o dia 21 de novembro de 2018}

A presente Monografia, apresentada pelo (a) aluno (a)

Dor s a clasherster

poderá ser submetida à exposição e defesa perante a Banca Examinadora designada pelo Departamento de Direito da PUC-Rio.

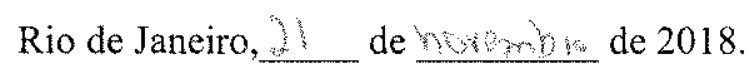

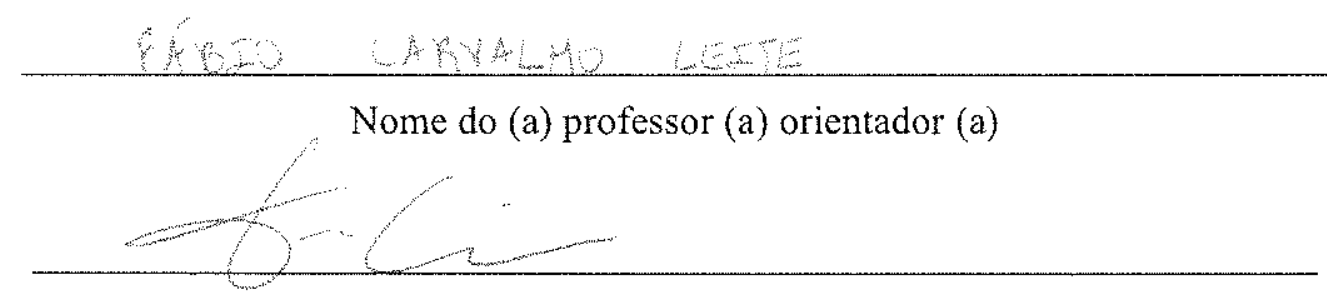

Assinatura do (a) professor (a) orientador (a)

$O(A)$ autor (a) deste trabalho declara para todos os fins de Direito ser este um trabalho inédito e autoriza o Departamento de Direito da PUC-Rio a divulgá-lo, no todo ou em parte, resguardados os direitos autorais conforme legislação vigente.

Rio de Janeiro, al de Wismio 2018.

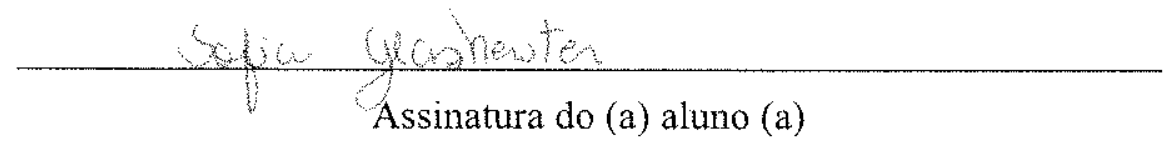

